\title{
Processes Driving Sea Ice Variability in the Bering Sea in an Eddying Ocean/Sea Ice Model: Mean Seasonal Cycle
}

\author{
Linghan Li ${ }^{\mathrm{a}, *}$, Julie L. McClean ${ }^{\mathrm{a}}$, Arthur J. Miller ${ }^{\mathrm{a}}$, Ian Eisenman ${ }^{\mathrm{a}}$, Myrl C. Hendershotta \\ Caroline A. Papadopoulos ${ }^{\mathrm{a}}$ \\ a Scripps Institution of Oceanography, La Jolla, CA 92093, United States
}

\footnotetext{
* Corresponding author at: Scripps Institution of Oceanography, La Jolla, CA 92093, United States. Tel.: +1 8584085282.

E-mail address: li.linghan.li@gmail.com (Linghan Li).
} 


\begin{abstract}
The seasonal cycle of sea ice variability in the Bering Sea, together with the thermodynamic and dynamic processes that control it, are examined in a fine resolution $\left(1 / 10^{\circ}\right)$ global coupled ocean/sea-ice model configured in the Community Earth System Model (CESM) framework. The ocean/sea-ice model consists of the Los Alamos National Laboratory Parallel Ocean Program (POP) and the Los Alamos Sea Ice Model (CICE). The model was forced with time-varying reanalysis atmospheric forcing for the time period 1980-1989. The simulated seasonal-mean fields of sea ice concentration strongly resemble satellite-derived observations, as quantified by root-mean-square errors and pattern correlation coefficients. The sea ice energy budget reveals that the seasonal thermodynamic ice volume changes are dominated by the surface energy flux between the atmosphere and the ice in the northern region and by heat flux from the ocean to the ice along the southern ice edge, especially on the western side. A sea ice force balance analysis shows that sea ice motion is largely associated with wind stress. The force due to divergence of the internal ice stress tensor is large near the land boundaries in the north, and it is small in the central and southern ice-covered region. During winter, which dominates the annual mean, it is found that the simulated sea ice was mainly formed in the northern Bering Sea, with the maximum ice growth rate occurring along the coast due to cold air from northerly winds and ice motion away from the coast. South of St. Lawrence Island, winds drive the model sea ice southwestward from the north to the southwestern part of the ice-covered region. Along the ice edge in the western Bering Sea, model sea ice is melted by warm ocean water, which is carried by the simulated Bering Slope Current flowing to the northwest, resulting in the S-shaped asymmetric pattern seen in the ice edge. In spring and fall, similar thermodynamic and dynamic patterns occur in the model, but with typically smaller magnitudes and with seasonspecific geographical and directional differences.
\end{abstract}

Keywords Sea ice; Ice growth/melt; Sea ice motion; Heat flux; Climate dynamics; Bering Sea 


\section{Introduction}

The subpolar North Pacific Ocean and the western Arctic basin are connected via the semi-enclosed Bering Sea. The sea ice distribution in this marginal sea is highly seasonal and is impacted by a vigorous mesoscale eddy field (e.g., Johnson et al., 2004). Its waters contain one of the most productive marine ecosystems in the world, and consequently support a large oceanic fishery for both commercial and subsistence use (e.g., Hunt et al., 2011). Hence this region is important both climatically and economically. Understanding the processes that control the temporal evolution of the sea ice distribution is vital to anticipating how the physical-biological system will change in future years and decades (e.g., Wang et al., 2012).

The dominant change in sea ice cover in the Bering Sea is associated with the seasonal cycle. A conveyor belt mechanism, with a northern source, a southern sink, and an intermediate zone where ice is transported southward by northerly winds, has been proposed to explain the basic north-south structure using observations alone (Muench and Ahlnas, 1976; Pease, 1980). These satellite and in situ observations (Muench and Ahlnas, 1976; Pease, 1980; Wang et al., 2009; Stabeno et al., 2001), however, provide a limited perspective on what controls the seasonal extent and thickness of the ice. So numerical simulations are needed to better understand the dynamics and thermodynamics of these variations.

Previous sea-ice modeling studies of the Bering Sea have revealed a strong sensitivity to the types of parameterizations used in the ice model, the structure of the background oceanic circulation, and the details of the atmospheric forcing. Bitz et al. (2005) studied global sea ice in version 2 of the National Center for Atmospheric Research Community Climate System Model (NCAR CCSM2), including thermodynamic and dynamic balances on a seasonal mean basis. They noted that in the Bering Sea, which is relatively far from the pole, the ice edge location is more strongly controlled by oceanic heating effects driven by solar absorption than by ocean heat flux convergence. Zhang et al. (2010), using the multicategory thickness and enthalpy distribution (TED) sea ice model (Zhang and Rothrock, 2001) embedded in the Los Alamos National Laboratory Parallel Ocean Program (POP), focused on interannual sea ice variations in the Bering Sea, which they found to be dominated by wind-driven changes in ice transport and the ocean thermal front in the southern Bering Sea. Using the Regional Ocean Modeling System (ROMS) that included a sea ice model, Danielson et al. (2011) showed that although the simulated seasonal structure of the sea ice pattern was realistic, the spring retreat of sea ice in the model was too slow compared to observations. Cheng et al. (2014) used the Community Earth System Model (CESM) to examine the effects of sea ice on the upper ocean on the shelf of the Eastern Bering Sea.

Because of the economic and climatic importance of the Bering Sea, a detailed investigation of the processes involved in establishing the climatological seasonal distribution of sea ice is needed. This can then form a baseline for determining the controls on the interannual changes in sea ice (see Li et al., 2014) and those associated with global warming on long time scales. 
We study the seasonal cycle of Bering Sea ice distribution in a forced global fineresolution ocean/sea-ice simulation in the CESM framework. The ocean/sea-ice model consists of POP and the Los Alamos Sea Ice Model (CICE). This simulation was run with Coordinated Ocean-Ice Reference Experiment version 2 (CORE2) interannually-varying atmospheric forcing.

In the following sections, we introduce the sea ice-ocean model (Section 2) and compare the simulated results with available satellite observations (Section 3). Next, we determine the relative importance of the terms in the thermodynamic and dynamic equations controlling sea ice volume variability (Section 4), and we examine the relationship between sea ice variability and atmospheric and oceanic conditions (Section 5). Lastly, we summarize the results and discuss directions for future work (Section 6).

\section{Coupled ocean/sea-ice model}

We use output from a fine resolution (nominally 1/10-degree) global coupled ocean/seaice simulation configured in the CESM framework (McClean et al., 2014, in preparation). The ocean and sea ice components are the LANL POP and CICE models that are coupled in CESM via Flux Coupler version 7 (CPL7) (Craig et al., 2012). This simulation was configured on a tripole grid with poles in Canada, Russia and Antarctica. Details of the global ocean bathymetry for this tripole grid are found in McClean et al. (2011). Figure 1 shows the ocean model bathymetry of the Bering Sea, as well as the regional temperature grid subsampled at ten grid point intervals. Sea-ice variability and its causes were studied in earlier forced coupled POP/CICE simulations configured at lower horizontal resolution, e.g., by Ivanova et al. (2012), Prasad et al. (2005), and Hunke et al. (2008).

POP is a $z$-level ocean general circulation model that solves the three-dimensional primitive equations for ocean temperature, salinity, and momentum (Dukowicz and Smith, 1994). It has an implicit free surface. Partial bottom cells were used for improved representation of flow over the bottom boundary. This POP configuration has 42 vertical levels whose thickness ranges from $10 \mathrm{~m}$ in the uppermost level to $250 \mathrm{~m}$ in the deep ocean. The horizontal resolution is around $6 \mathrm{~km}$ in the Bering Sea. Weak surface salinity restoring with an effective timescale of about 4 years was used in this simulation to limit model drift. This version of POP uses the K-Profile Parameterization (KPP) for vertical mixing. It does not include tidal forcing.

CICE utilizes the energy-conserving thermodynamic sea ice model of Bitz and Lipscomb (1999) to compute ice/snow growth and melt rates. CICE has one thermodynamic snow layer and four thermodynamic ice layers. CICE uses a subgridscale ice thickness distribution with five ice thickness categories: $0.00 \mathrm{~m}-0.60 \mathrm{~m}, 0.60 \mathrm{~m}-1.40 \mathrm{~m}, 1.40 \mathrm{~m}-$ $2.40 \mathrm{~m}, 2.40 \mathrm{~m}-3.60 \mathrm{~m},>3.60 \mathrm{~m}$. For each ice thickness category, the model calculates the ice and snow thickness changes and vertical temperature profiles based on vertical radiative, turbulent, and conductive energy fluxes. The model includes the effect of brine pockets on effective specific heat capacity and thermal conductivity due to internal melting and freezing. The salinity is prescribed to follow a vertical profile that is constant 
in time. CICE uses the elastic-viscous-plastic (EVP) sea ice dynamic model of Hunke and Dukowicz (1997) to compute ice velocities. The ice momentum equation involves 5 terms: wind stress, ocean stress, divergence of the internal ice stress tensor, the Coriolis force, and gravitational force due to the sea surface slope. CICE uses an incremental remapping advection scheme to transport sea ice in various thickness categories (Lipscomb and Hunke, 2004).

This ocean/sea ice simulation was forced with daily CORE2 interannually-varying atmospheric forcing from 1970-1989 (Large and Yeager, 2004; 2009). CORE2 fluxes are based upon 6-hourly (1948-2006) near-surface vector wind, specific humidity, density, and air temperature based on National Center for Environmental Prediction (NCEP) reanalysis, daily downward radiation (1984-2006) from International Satellite Cloud Climatology Project (ISCCP) data (Zhang et al., 2004), and monthly precipitation (19792006) from a combination of satellite observations. Climatological mean annual cycles are used for all radiation fluxes (1948-1983) and precipitation (1948-1978) before the satellite observing periods. Some data sets are adjusted using observations. Over the Arctic cap north of $70^{\circ} \mathrm{N}, 12$ monthly adjustments are made to the surface air temperature based on the polar exchange at the sea surface (POLES) data (Rigor et al., 2000). Adjustments are also made to the NCEP vector winds using QSCAT satellite scatterometer wind vectors. Turbulent fluxes are obtained using bulk formulae, the near surface NCEP atmospheric state, and upper-level model temperature and velocity (Large and Yeager, 2004, 2009; Griffies et al., 2009; Griffies et al., 2012). CORE2 is on a T62 grid with a horizontal resolution of $\sim 100 \mathrm{~km}$ (east-west) and $\sim 200 \mathrm{~km}$ (north-south) in the Bering Sea. This CORE2 forcing was also used by Danielson et al. (2011) to drive Bering Sea simulations using ROMS (Haidvogel et al., 2008).

This simulation was integrated for years 1970-2009. At the time of our analyses the model had only been run through 1989. Hence, we present results from 1980-1989 as the first 10 years (1970-1979) were treated as a spin-up period. The sea-ice was initialized using uniform $2 \mathrm{~m}$ thick ice delineated by an ice edge that was chosen to be consistent with the location of the climatological $15 \%$ sea ice concentration contour from the Special Sensor Microwave Imager (SSM/I) data for January. The ocean was initialized from rest using potential temperature and salinity from the World Hydrographic Program Special Analysis Center (WHP SAC) climatology (Gouretski and Koltermann, 2004). See McClean et al. (2014) for further details.

The model saves monthly-mean variables along with accumulated terms in the thermodynamic and dynamic balances (e.g., ice volume tendency terms due to thermodynamics and dynamics). The primary equation of interest is the equation partitioning the ice volume tendency $\frac{V}{t}$ (partial time derivative of ice volume) into two components:

$$
\frac{V}{t}=\frac{V_{T}}{t}+\frac{V_{D}}{t}
$$


where the first term $\left(\frac{V_{T}}{t}\right)$ on the right-hand side is the ice volume tendency due to thermodynamics, and the second term $\left(\frac{V_{D}}{t}\right)$ on the right-hand side is the ice volume tendency due to dynamics. The dynamic component of the ice volume tendency is determined by the convergence of the product of ice velocity and ice volume

$\frac{\partial V_{D}}{\partial t}=\nabla \cdot(\vec{u} V)$

where $\vec{u}$ is ice velocity.

The thermodynamic component of the ice volume tendency can be further separated into the growth rate and the melt rate

$$
\frac{V_{T}}{t}=\mathrm{G}+\mathrm{M}
$$

where $\mathrm{G}$ is the growth rate, representing a sum of congelation ice growth, frazil ice growth, and snow-ice formation, and $\mathrm{M}$ is the melt rate, representing a sum of basal melt, lateral melt, and surface melt. Here the melt rate $\mathrm{M}$ is negative, meaning it contributes to ice volume decrease. Basal melt and congelation ice growth are determined by the difference between the net heat flux from the ocean to the ice and the conductive heat flux at the bottom surface of the ice. Surface melt is determined by the difference between the net energy flux from the atmosphere to the ice and the conductive heat flux from the top ice surface to the ice interior. The melt rate is broken up into the basal and lateral melt rate and the surface melt rate

$\mathrm{M}=\mathrm{M}_{\mathrm{BL}}+\mathrm{M}_{\mathrm{S}}(4)$

where $\mathrm{M}_{\mathrm{BL}}$ is the sum of basal and lateral melt rates, $\mathrm{M}_{\mathrm{S}}$ is the surface melt rate, and both terms are negative.

\section{Comparison with observations}

We first consider how well the model captures the regional variability of the spatial extent of sea ice during the time period of the run, 1980-1989. We obtained observed ice concentration (i.e., fractional sea ice cover), which varies from 0 to 1 , from satellite passive microwave data on a nominally $25 \mathrm{~km}$ grid. We used Bootstrap Sea Ice Concentrations from Nimbus-7 SMMR and DMSP SSM/I-SSMIS, which is publicly available at National Snow \& Ice Data Center (Comiso 2000). This dataset has an error of approximately $5-10 \%$ that varies with season, and the error is larger for thin ice and ice undergoing surface melting, especially near the ice edge. Here we follow the standard convention of defining the "ice edge" as the $15 \%$ ice concentration contour line. "Ice area" is defined as the sum of ice concentration multiplied by the grid cell area for grid cells where ice concentration is at least $15 \%$, considering only the Bering Sea region 
(south of the Bering Strait, north of Aleutian Islands, and bounded by land in the east and the west).

Figure 2a shows the monthly-mean sea ice area in the Bering Sea for both model and observations during the 1980-1989 time period. The model tracks the observed seasonal evolution of sea ice rather closely and captures many aspects of the interannual variability as well. A bias exists, however, in that the model tends to have too little ice in cold months. The ROMS model simulation of Danielson et al. (2011), similarly forced with CORE2, also had a bias towards too low ice area. Ivanova et al. (2012), in contrast, simulated a winter-mean ice distribution during 1990-2002 in POP-CICE (nominal 0.4 ${ }^{\circ}$ grid and forced with NCEP/NCAR forcing) that had larger concentrations than NASATEAM SSM/I satellite observations in the Bering Sea, as shown in their Figure 3.

Figure $2 \mathrm{~b}$ shows the 10 -year climatological seasonal cycle of the ice area in the Bering Sea from the model and observations. The model tracks the observed seasonal cycle well and reproduces the rapid retreat of sea ice in spring. However it shows a low bias in fall, winter and early spring (6-20\% from December to April). Although the model sea ice retreat is slightly slower than observations, it appears to retreat more rapidly than ROMS, based on the similar plot seen in Figure 11 of Danielson et al. (2011).

The model underestimation of the Bering Sea ice area may be associated with the lack of tidal effects in the POP-CICE model, which could be important over the shallow Bering continental shelf. Zhang et al. (2010) show that the difference in model sea ice thickness with and without tides is up to $0.1 \mathrm{~m}$, or $15 \%$, in the central-eastern Bering Sea. Hermann et al. (2002) show the tidal dynamics can promote vertical mixing and account for a large percentage of total kinetic energy of ocean currents in the southeastern Bering Sea. Auad and Miller (2008) show that tidal forcing might slow down the mean flow due to the horizontal gradient of tidal mixing. It is also likely that uncertainty in the atmospheric forcing, especially radiative forcing, at high latitudes could cause this model bias.

We next address the seasonal mean structures of sea ice in the model compared with observations. We define winter as January-March, spring as April-June, summer as JulySeptember, and fall as October-December. Figure 3 shows the seasonal means (fall, winter, spring, and summer) of ice concentration for 1980-1989 from the model (a-d) and satellite observations (e-h), as well as the difference between the two (i-l). In winter (Figure $3 b, f$, and $j$ ), the spatial structure of model ice concentration appears to be very similar to the observed ice concentration, except near the eastern coastal region and the Kamchatka coastal region where the model has too little ice. In fall (Figure 3a, e, and i), there is a substantial low bias of ice in Norton Sound and along the eastern coast and a high bias in the Gulf of Anadyr. In spring (Figure 3c, g, and k), the model simulates too much ice in the Gulf of Anadyr and too large an ice concentration maximum in the central Bering region. The model also produces less ice near much of the coast than is evident in the observations. In these coastal areas, the model simulates small-scale polynya-like features, which may not be accurately captured by the lower-resolution satellite observations ( $25 \mathrm{~km})$ due to land-to-ocean spillover effects (Parkinson et al., 1987; Maslanik et al., 1996). In summer, no ice is observed in Figure 3h, but the model 
contains some small regions with some ice near the coast of the Gulf of Anadyr in Figure $3 \mathrm{~d}$ (discernible on close inspection of Figure $3 \mathrm{~d}$ ).

We quantify the model-data mismatch by computing several statistics: Total ice area with ice concentration greater than $15 \%$, mean ice concentration for areas with greater than $15 \%$ concentration, RMS ice concentration error, and spatial pattern correlation for areas where both model and observations contain non-zero ice concentration. These results are presented in Table 1. Simulated ice area has a low bias in fall ( $25 \%$ less ice than observations) and winter ( $15 \%$ less). The model simulates slightly too much ice in summer, when essentially no ice is observed in the Bering Sea (although satellite-derived observations may fail to detect very low ice concentrations due to factors including the filtering of weather effects). In terms of mean ice concentration of the ice-covered area, the model value is very similar to observations for fall, winter, and spring. The normalized root-mean-square (RMS) error of ice concentration is small in winter $(0.16)$ and spring (0.22) but moderately large in fall (0.43). The spatial pattern correlation is very high in winter (0.97) and spring (0.94) and only slight weaker in fall (0.81).

Statistics in summer are poorly defined due to only limited spotty regions of observed ice.

Overall, these results suggest that this POP-CICE simulation captures the main observed spatial patterns and magnitudes of ice coverage and concentration in the Bering Sea.

Since these results attest to the realism of the simulated sea ice, we therefore consider this simulation a suitable tool to study the model processes that control the temporal and spatial structures in the seasonal evolution of sea ice in this region.

\section{Thermodynamic and dynamic balances}

We next consider the thermodynamic and dynamic balances controlling the climatological seasonal cycle of sea ice in the Bering Sea. Figures 4-7 show, for each season, the key terms affecting the ice volume tendency $\left(\frac{V}{t}\right.$, Figures $\left.4-7 a\right)$. Since this term is nearly zero for the annual mean and since the balances in winter tend to dominate the annual mean, we do not plot the annual mean results. The other panels in each figure correspond to the ice volume tendency due to dynamics $\left(\frac{V_{D}}{t}\right.$, Figures $\left.4-7 \mathrm{~b}\right)$, the ice volume tendency due to thermodynamics $\left(\frac{V_{T}}{t}\right.$, Figures $\left.4-7 \mathrm{c}\right)$, the ice growth rate $(\mathrm{G}$, Figures 4-7d), the basal plus lateral melt rate ( $\mathrm{M}_{\mathrm{BL}}$, Figures 4-7e), and the surface melt rate $\left(\mathrm{M}_{\mathrm{S}}\right.$, Figures 4-7f). The thermodynamic ice volume tendency $\left(\frac{V_{T}}{t}\right)$ is the ice volume change due to ice growth (including congelation ice growth, frazil ice growth, and snow ice formation) and ice melt at the bottom, surface, and lateral sides of sea ice, and positive/negative values mean ice volume increase/decrease due to thermodynamic processes. The dynamic ice volume tendency $\left(\frac{V_{D}}{t}\right)$ is the ice volume change due to ice 
motion, and positive/negative values mean ice volume increase/decrease resulting from ice transport into/out of a certain area. The net ice volume tendency $\left(\frac{V}{t}\right)$ is the sum of thermodynamic ice volume tendency $\left(\frac{V_{T}}{t}\right)$ and dynamic ice volume tendency $\left(\frac{V_{D}}{t}\right)$.

In the fall (Figure 4), ice forms primarily in the open-ocean region of the northeastern Bering Sea between St Lawrence Island and Norton Sound and along the coastal region (Figure 4d) to the northwest of Cape Navarin, yielding an S-shaped ice edge. The ice volume tendency is positive over the entire region containing ice as shown in Figure 4a. Although ice growth (Figure 4d) dominates the thermodynamic tendency (Figure 4c), some significant basal/lateral melting occurs near the coast of the Gulf of Anadyr (Figure $4 \mathrm{e})$. We use a convention whereby ice melt is assigned negative values here rather than the positive values it has in the model simulation to simplify our interpretation of the ice volume tendency terms. Surface melting is very weak at this time (Figure 4f), as it is in all seasons. The dynamic ice volume tendency shown in Figure $4 \mathrm{~b}$ implies a transport of ice from the coastal regions of the northern Bering Sea to build up the sea ice southwestward of St Lawrence Island and in the Gulf of Anadyr, where some open-ocean melting also occurs in Figure 4e.

In winter (Figure 5), when sea ice reaches its maximum extent, strong ice growth rates occur near all the northern Bering Sea coastal regions, including southeastward into the northern Bristol Bay (Figure 5d). Growth rates are also high in open oceans ranging diagonally from the northwest to the southeast across the northern Bering Sea (Figure 5d). As shown in Figure 5b, dynamical export of ice occurs over much of that same growth region, moving the ice into the warmer waters southwest of the marginal ice zones where significant basal/lateral melting occurs (Figure 5e). In Figure 5a, two hot spots of ice volume increase occur due to the blockage of transport by land, one northeast of St Lawrence Island and one in the southwestern Gulf of Anadyr, and consequently ice thickness reaches a maximum there (Figure 11f). In the coastal polynya regions of the northern Bering Sea, the thermodynamic ice growth in Figure 5c and dynamical ice export in Figure $5 b$ are very nearly in balance. In the central Bering Sea near the ice edge, significant ice volume increase still occurs (Figure 5a), with more ice volume being transported in (Figure 5b) than is melted (Figure 5c).

In spring (Figure 6), as the ice retreats, the volume tendency is negative everywhere as the ice cover decreases, as shown in Figure 6a. Although the growth rate is still positive in the higher latitude region (Figure 6d), the basal/lateral melt rate (Figure 6e) is high, especially in the southwestern Bering. The net thermodynamic tendency (Figure 6c) indicates a loss of ice everywhere except in small coastal and island regions in the northern Bering Sea. Strong ice transport out of the northern Bering Sea (Figure 6b) dominates the weak ice growth (Figure 6c), causing the net ice volume to decrease (Figure 6a). Although ice is transported into the southwest near the ice edge (Figure 6b), local melting dominates (Figure 6e). Some relatively small surface melting occurs in the northwestern Gulf of Anadyr (Figure 6f). 
In summer (Figure 7 ), there is only a small amount of ice with $\sim 5 \%$ concentration along the coast of the Gulf of Anadyr. The little remaining ice in this region decreases (Figure 7a) due to basal/lateral melt effects (Figure 7e) along with weak surface melting (Figure $7 \mathrm{f}$ ) and dynamical transport (Figure $7 \mathrm{~b}$ ) as it breaks apart.

Note that the surface melt term is very small in all seasons in the Bering Sea (Figures $4 \mathrm{f}$, $5 \mathrm{f}, 6 \mathrm{f}$, and $7 \mathrm{f}$ ). Issues associated with the CICE treatment of melt ponds on sea ice (Flocco et al., 2012) are therefore not expected to be relevant in this region.

This analysis of ice volume tendencies reveals large differences for the northern region, which is dominated by ice growth and ice outflow in winter, compared with the southern region, which is dominated by melting and ice inflow. To display the seasonal evolution of this basic structure, spatial averages of the tendency terms were computed for two boxes (Figure 1), one in the northern ice growth region $(\mathrm{a} 90 \mathrm{~km} \times 60 \mathrm{~km}$ box centered at $\left.63.76^{\circ} \mathrm{N}, 173.01^{\circ} \mathrm{W}\right)$ and one in the southern ice melt region $(\mathrm{a} 127 \mathrm{~km} \times 100 \mathrm{~km}$ box centered at $60.89^{\circ} \mathrm{N}, 178.31^{\circ} \mathrm{W}$ ), for each month of the year (Figure 8). Ice growth dominates the thermodynamic tendency in the northern box from December to April, after which basal/lateral melting becomes the most significant term until summer when both tendencies are effectively zero. Ice transport out of the northern box gives a strongly negative contribution and keeps the ice volume tendency close to zero, though slightly positive, throughout the winter months. In the southern box, the reverse happens in winter months. A strong dynamic influx of ice occurs from February through May, with a maximum in March, while substantial bottom melting nearly balances that input, resulting in a weak positive net ice volume tendency in winter and a weak negative value in spring. From May through July, when the ice edge moves near the northern box, the average in the northern box behaves like an attenuated version of the southern box.

Next we consider the total ice volume tendency summed over all the grid cells in the Bering Sea, which represents the time rate of change of total ice volume in the Bering Sea. Monthly climatological rates are shown in Figure 9. The time rate of change of total ice volume becomes positive from November and reaches its annual maximum value in January. During February and March, the rate is still positive but lower than the January maximum. It becomes negative in April and the ice volume loss is greatest in May. The seasonal cycle of the total ice volume tendency is dominated by the thermodynamic tendency. The contribution of the dynamic tendency is relatively small. This dynamic tendency is positive only in November, is negative from December to July, and it attains its most negative value in April. During the winter months (December - March), the dynamic tendency and thermodynamic tendency have opposite signs; hence the dynamic tendency reduces the gains by the thermodynamic tendency. During spring (April-July) and fall (November) months, the dynamic tendency and thermodynamic tendency have the same sign, producing enhanced losses of ice in the spring and enhanced gains of ice in the fall.

\section{Relationship between sea ice variability and atmospheric and oceanic conditions}

\subsection{Covariability of ice with atmosphere-ocean fields}


While the terms in the ice volume tendency equation give us a picture of the overall processes at work in creating, transporting, and melting ice, they do not clearly differentiate between the various driving factors in the atmospheric and oceanic system. For example, although ice is transported laterally from the north to the south in winter, the transport could be due to wind forcing or to advection by ocean currents. In this section, we address the relationship between ice variables and large-scale and regionalscale patterns in the winds, surface air temperature, ocean currents, and sea surface temperature.

The major ocean currents in the Bering Sea are shown in Figure 2 of Stabeno et al. (1999). The Alaskan Stream flows westward along the southern side of the Aleutian Islands. In the western basin $\left(168^{\circ}-172^{\circ} \mathrm{E}\right)$, a portion of this current enters the Bering Sea through the Amchitka and Amukta Passes, and then it flows eastward along the northern side of the Aleutian Islands as the Aleutian North Slope Current (ANSC). The ANSC feeds the Bering Slope Current (BSC) that flows cyclonically around the Bering basin: the BSC flows northwestward along the shelf break until it reaches the mid-basin where it veers away from the slope forming a broad weak westward flow that intensifies again on arriving at the coast where it forms the southward flowing Kamchakta Current. The Anadyr Current flows northward along the northwest sector of the Bering Sea. Finally, waters transported by the Anadyr Current in the western basin, the Alaska Coastal Current in the east, and mid-basin Bering Shelf Waters flow through the Bering Strait into the Arctic Ocean (Stabeno et al., 1999).

In the fall season, northwestward ocean flow along the Bering shelf break causes the sea surface temperature (SST) to be warmer in the northwestern shelf region than in the northeast, as shown in Figure 10i. As cold northerly winds blow (Figure 10a), ice forms most actively along the northern coastal regions of the Bering Sea. Ice also forms over the eastern, cooler part of the asymmetric SST pattern in the open ocean region of the northeastern shelf (Figure 10i). From there, ice is transported southwestward (Figure 10e) by the very strong northeasterly winds (Figure 10a) to the warmer SST region, where ice melts (Figure 10i). This creates a very broad marginal ice zone (Figure 3a), in contrast to winter conditions where the transition is sharp near the ice edge (Figure $3 b$ ).

In the winter season, the ice typically moves southwestward, and maximum velocities occur along the western ice edge (Figure 10f). The wind field in winter (Figure 10b) over the ice-covered Bering Sea exhibits strong northeasterly flow, which is consistent with wind-forced transport of the ice with a small rotation angle to the right. The wind strength is somewhat greater towards the western Bering ice-covered area (Figure 10b), which renders the surface wind stress on the ice (not shown) greater there than in the east. The net result is transport of ice from the northern region, where it is generated locally mostly by coastal polynyas opened by the northerly winds, to the southwestern icecovered area, where it is melted along the ice edge. The stress of the ocean on the ice (not shown) is slightly weaker than the wind stress on the ice and acts in the opposite direction. This, combined with the ocean currents tending to flow westward under the 
ice-covered central region (Figure 10j), implies weak effects of large-scale oceanic advection of ice in this season.

Ocean currents do appear to play a substantial role in creating the asymmetry in the ice edge during winter, when the ice edge penetrates further southward in the east than in the west. As shown in Figure 10j, the Bering Slope Current carries warmer surface water from the southeastern Bering region to the western edge of the ice-covered area where melting occurs at higher latitudes than in the east (Figure 5e). Ocean-ice heat flux in winter (not shown) reveals strong warming of ice along the western ice edge, which results in the large basal ice melting seen in Figure 5e. The melting in this region occurs under the ice far from the ice edge, possibly due to the lateral mixing effects of only partially resolved energetic oceanic eddies that occur along the Bering Slope Current in the model as well as in the real world (e.g., Johnson et al., 2004). This is in contrast to the eastern ice edge, where basal melting is strongest very close to the ice edge.

Air temperature (Figure 10b) correlates well with ice concentration (the black line is the $15 \%$ ice concentration contour). Atmosphere-ice energy flux in winter (not shown) reveals substantial cooling in the northern Bering Sea near the coastal regions, where ice tends to be thinner than further offshore (Figure 10f). This is consistent with the idea that coastal polynyas form there due to the southward ice transport by the model northerly wind (Figures $10 \mathrm{~b}$ and $\mathrm{f}$ ). The largest growth rates occur along the northern coastal regions as seen in Figure 5d, probably associated with the fact that the thinner ice around the coastal polynyas grows faster (due to the conductive heat flux being approximately inversely related to the ice thickness).

In spring, sea ice volume decreases throughout the ice-covered region. Ice is still produced in the north, where the air temperature (a specified forcing) is consistently less than $0^{\circ} \mathrm{C}$ (Figure 10c). As shown in Figure 10g, north of St Lawrence Island, ice is transported northward through the Bering Strait into the Arctic, likely by the influence of the ocean stress induced by the Anadyr Current (Figure 10k). In the broader regions south of St Lawrence Island, ice moves westward (Figure 10g) following the combined effects of weak northeasterly winds (Figure 10c) and the northwestward ocean currents (Figure $10 \mathrm{k}$ ). Along the western parts of the ice edge, very strong basal and lateral melt driven by strong ice-ocean heat fluxes consumes ice transported into the region. From there, the Bering Slope Current carries ice towards the coast, where the Kamchatka Current transports the ice across Shirshov Ridge and along the coast of the Kamchatka Peninsula (Figures $10 \mathrm{~g}$ and $\mathrm{k}$ ). Along the eastern edge of the Bering Shelf, there is less ice near the coast (Figure 10g) associated with warmer air temperatures (Figure 10c).

In summer, there is almost no ice in the Bering Sea. Only a very small amount of ice exists along the coast of the Gulf of Anadyr (Figure 3d). Basal/lateral melt from the warm ocean surface (Figure 101) and weak surface melt from warm air (Figure 10d) occur there. Ice moves northeastward through the Anadyr Strait and Bering Strait (Figure 10h) following the ocean currents (Figure 101).

\subsection{Local forcing of sea ice variability}


Now we consider the local forcing of the seasonal cycle of ice volume changes for one site in the northern ice growth region and one site in the southern ice melt region in section 4 (the two sites are marked on Figure 1).

First, we consider thermal forcings: the surface energy flux between the atmosphere and the ice, as well as the oceanic heat flux between the ocean and the ice. Energy flux into the ice is indicated by positive values. As shown in Figure 11, in the north, the seasonal cycle of the surface energy flux corresponds closely with the thermodynamic tendency (Figure 8 and Figure 11); in the south, the oceanic heat flux climatology coincides with the thermodynamic ice volume tendency (Figure 8 and Figure 11). Second, we consider the mechanical forcing: wind stress and ocean stress. The wind stress broadly agrees with the seasonal dynamic ice volume tendency (Figure 8 and Figure 11).

Overall, on a seasonal basis, the thermodynamic ice volume change in the north is dominated by ice growth, which is driven by surface energy flux between the ice and the atmosphere; along the southern ice edge, the thermodynamic ice volume change is mainly due to basal melt driven by the ocean heat flux into ice. The dynamic ice transport is largely associated with wind stress.

\subsection{Sea ice energy budget}

We also examine the seasonal-mean energy budget for sea ice. Net surface energy flux between the ice and the atmosphere is the sum of net shortwave radiation, net longwave radiation, latent heat flux, and sensible heat flux. Latent heat flux is the flux between the sea ice cover and the atmosphere that is associated with sublimation of snow or snow-free ice at the surface and deposition of vapor from the atmosphere at the surface as snow or ice. Sensible heat flux is the flux associated with the difference between near-surface air temperature and the surface temperature of snow or snow-free ice. Oceanic heat flux is associated with the difference between temperature of the ocean below the ice and the salinity-dependent freezing temperature.

As shown in Figure 12a, the climatological winter-mean net surface energy flux is large in the northern Bering Sea, with the largest heat loss from the ice to the atmosphere occurring in the coastal regions. As shown in Figure 12d, the heat flux from the ocean to the ice dominates the southwestern ice cover, with the largest values occurring along the western ice edge due to the warm Bering Slope Current that flows from the southeast into this region. Among the components of the net surface energy flux, sensible heat flux and net longwave radiation are large, while the net shortwave radiation and latent heat flux are insignificant. Sensible heat flux is large in coastal regions, and hence is largely responsible for the co-located extremum in the net surface energy flux (Figure 12f). Net longwave radiation contributes to the net surface energy flux on an overall basin scale (Figure 12e). In spring, the ocean heat flux acts over a large area especially in the western ice-covered area (Figure 12j). The net surface energy flux is weak in the north (Figure $12 \mathrm{~g}$ ) as a result of relatively strong net shortwave heating (Figure 12h) and net longwave 
cooling (Figure 12k), weak sensible heat warming in the south and cooling in the north (Figure 12l), and very weak latent heat warming (Figure 12i).

\subsection{Sea ice force balance}

In this section we quantify the sea ice force balance in the Bering Sea to understand how the dominant balance changes between winter and spring. The momentum equation per unit area of sea ice consists of five terms: wind stress, ocean stress, divergence of the internal ice stress tensor, the Coriolis force, and gravitational force due to the sea surface slope. It is

$$
m \frac{\partial \vec{u}}{\partial t}=\vec{a}_{a}+{ }_{w}+\nabla \cdot \quad \hat{k} \times m f \vec{u} \quad m g \nabla H_{o}
$$

where $\mathrm{m}$ is the combined mass of ice and snow per unit area, $u$ is the ice velocity, $\overrightarrow{ }_{a}$ is the wind stress on the ice, ${ }_{w}$ is the ocean stress on the ice, $\nabla \cdot$ is the divergence of the internal ice stress tensor, $\hat{k} \quad m f \vec{u}$ is the Coriolis force, and $m g \nabla H_{o}$ is the gravitational force due to the sea surface slope with sea surface height $\mathrm{H}_{0}$ relative to the geoid. Monthly-mean wind stress on the ice, ocean stress on the ice, divergence of the internal ice stress tensor, and Coriolis force are archived in the model output. We reconstruct the gravitational force due to the sea surface slope based on model outputs of sea surface height, ice thickness, and snow thickness.

The magnitudes of wind stress on the ice, ocean stress on the ice, the Coriolis force, divergence of the internal ice stress tensor, gravitational force due to sea surface slope, and their sum in winter and spring are compared in Figure 13a-f and Figure 14a-f, respectively. In winter, the wind stress and the ocean stress are large and have similar magnitudes and spatial distribution; the ocean stress is slightly weaker than the wind stress, especially near the coasts, as shown in Figure 13a,b. The divergence of the internal ice stress tensor (Figure 13d) is large in the southern part of the Gulf of Anadyr and north of St Laurence Island, and it is small in the central and southern ice-covered area. The Coriolis force (Figure 13c) and the gravitational force due to the sea surface slope (Figure 13e) are the smallest among these terms, but the gravitational force due to the sea surface slope is significant in some local regions near land, e.g., near the Bering Strait (Figure 13e). These five terms balance with nearly zero net force everywhere in the Bering Sea (Figure 13f), indicating a force equilibrium where ice acceleration is relatively small on the seasonal-mean timescale. In spring, wind stress and ocean stress are much smaller than in winter, and they attain their maximum values in the western ice-covered area, as shown in Figure 14a,b. The ocean stress is generally weaker than the wind stress. The divergence of the internal ice stress tensor (Figure 14d) is largely reduced, and is only important in the southern Gulf of Anadyr, immediately north of St Lawrence Island and near the Bering Strait, where its magnitude is similar to the magnitude of the wind stress. The Coriolis force (Figure 14c) and the gravitational force due to sea surface slope (Figure 14e) are weak. The sea ice is in nearly equilibrium force balance in spring (Figure 14f). 
Since the largest two force terms (wind and ocean stresses) are nearly counterbalancing each other (not shown), which is consistent with wind-driven ice flow, with ocean drag, it is useful to examine the residual sum of these two terms in relation to the other (smaller) force terms. In Figure 13g-j and Figure 14g-j, we compare this residual sum to the divergence of the internal ice stress tensor, the Coriolis force, and the gravitational force due to sea surface slope for winter and spring climatological means. The winter residual sum (Figure 13g) has a magnitude and spatial distribution that are similar to the divergence of the internal ice stress tensor (Figure 13i). Near the southern part of the Gulf of Anadyr and north of St Laurence Island, these two terms are large (Figure 13g,i). In the southern and central ice-covered area, the Coriolis force (Figure 13h) is small, but it is comparable with divergence of the internal ice stress tensor (Figure 13i) and the residual sum (Figure 13g). In spring, the divergence of the internal ice stress tensor (Figure 14i) and the residual sum (Figure 14g) are similar to winter but weaker. In the southern and central ice-covered area, the divergence of the internal ice stress tensor (Figure 14i), the residual sum (Figure 14g), and the Coriolis force (Figure 14h) all have similar magnitudes.

In summary, the wind stress is the largest force term, and the ocean stress is the second largest. These two terms have similar magnitudes and spatial distributions. The divergence of the internal ice stress tensor can be important at some local spots near the land boundaries in the north, but it is small in the central and southern ice-covered region. The sum of wind stress and ocean stress has a similar magnitude and spatial distribution to the divergence of the internal ice stress tensor. The Coriolis force and the gravitational force due to sea surface slope are small, but along the ice edge the Coriolis force has a magnitude close to the divergence of the internal ice stress tensor and the sum of wind stress and ocean stress. The sum of these five force terms is nearly zero, producing nearly zero ice acceleration.

\section{Summary and Discussion}

We evaluated the skill and the relevant dynamic and thermodynamic balances for the mean seasonal cycle of sea ice in the Bering Sea during 1980-1989 in a 1/10-degree POPCICE simulation. We found close agreement between the simulated and observed sea ice concentration in each season, except for a relatively small bias towards less ice than observed. Since winter is the season with the greatest amount of sea ice, and since the annual-mean structure is most similar to that of winter, we present a schematic broadscale depiction of the dominant processes controlling the Bering Sea ice structure in wintertime in Figure 15.

This schematic indicates how ice is created, transported, and melted in winter. In the northern Bering Sea, the northeasterly wind brings cold air, which freezes the ocean surface, causing ice to grow there. The wind also opens coastal polynyas where the ice growth rate attains its maximum values. South of St. Lawrence Island, wind stress drives ice to move southwestward, so that ice is transported from the north to the southwestern ice-covered area (Pease 1980; McNutt 1981a, 1981b). Along the southern ice edge, especially in the west, ice is melted by warm ocean water. These warm waters are carried 
by the Bering Slope Current that is flowing northwestward, resulting in an S-shaped asymmetric ice edge. This general picture is consistent with a conveyor belt with a northern source, a southern sink, and an intermediate zone where ice is transported southward by northerly winds (Muench and Ahlnas, 1976; Pease, 1980).

We also examined what drives the seasonal cycle of sea ice in the Bering Sea, including the energy budget and the force balance for sea ice. Seasonal thermodynamic ice volume changes are dominated by the surface energy flux between the atmosphere and the ice in the north and by the heat flux from the ocean to the ice along the southern ice edge, especially on the western side. Sea ice motion is largely associated with wind stress. Divergence of the internal ice stress tensor is large near the land boundaries in the north, and it is small in the central and southern ice-covered area.

The dynamic ice transport acts in opposition to the thermodynamic ice volume tendency locally throughout the ice-covered months (Figure 8). As shown in the monthly climatology plot in Figure 8, the dynamic ice volume tendency and thermodynamic ice volume tendency are opposite to each other with similar magnitudes, leaving a small residual net ice volume tendency, both in the northern growth region and in the southwestern melt region. Yet dynamic ice transport also plays a role in enhancing the thermodynamic growth in the northern region in winter as ice is transported out of the region where it is formed, which promotes further ice growth there. Likewise, ice is dynamically transported into the warmer southern region where it is melted, so that more ice transport contributes to a larger ice melt rate near the ice edge. In winter, the process of ice growth, transport, and melt reaches its maximum when the strong northeasterly winds drive the strongest southwestward ice transport. However, integrated over the entire Bering Sea, the seasonal cycle of the total ice volume tendency is dominated by the thermodynamic tendency, and the contribution of the dynamic tendency is relatively small, as shown in Figure 9. Note that the dynamic ice volume tendency integrated over the Bering Sea is equal to the ice transport through the boundary (mainly through the Bering Strait).

The thermodynamic and dynamic tendencies of ice volume exhibit opposite-signed dipole patterns in their spatial distributions (Figure 4-7). The 1980-89 annual-mean net ice volume tendency reveals that these two terms are nearly in balance everywhere. Overall, thermodynamic volume changes dominate in the north in fall and winter when ice is produced, and they also dominate in the southwest in spring when ice melts. Dynamic changes dominate the ice volume increase near the western ice edge in fall and winter through ice influx, as well as the ice volume decrease in the north in spring through ice transport out of the northern region.

The dynamic balance is largely associated with the wind forcing, while the thermodynamic balance involves several aspects of the atmospheric and oceanic system. Polynyas occur along the coast in the north, produced by northerly winds, and cold air temperature promotes ice growth in the northern Bering Sea. The Bering Slope Current brings warm water northwestward towards the western ice edge where wind-driven ice import occurs, and substantial ice melt occurs there. This competition between the 
atmospheric winds and ocean currents largely controls the S-shaped structure of the ice edge.

The thermodynamic and dynamic balances presented in this paper are broadly consistent with other studies. Bitz et al. (2005) show a similar spatial distribution of thermodynamic and dynamic ice volume tendencies in winter. Zhang et al. (2010) show less east-west asymmetry in thermodynamic volume changes in winter, though their north-south distribution of growth and melt and dynamic ice transport in winter broadly agree with our results. Zhang et al. (2000) show that the dynamic and thermodynamic effects of sea ice in the Arctic Ocean are also opposite. Cheng et al. (2014) show spatial patterns of thermodynamic and dynamic ice area tendencies in February, which are largely consistent with our ice volume tendencies in winter.

Our analysis has demonstrated the skill of POP-CICE in representing the observed seasonal cycle of sea ice concentration in the Bering Sea during 1980-1989. The model allows a clear depiction of the important balances controlling the sea ice variability. Further work is needed to evaluate the time evolution of the anomalies from the mean seasonal cycle analyzed here, including the impacts of anomalous winds, surface energy fluxes, fluctuating currents and mesoscale eddy effects. This is the topic of a follow-up study (Li et al., 2014).

\section{Acknowledgements}

This study forms a portion of the Ph.D. dissertation of LL at Scripps Institution of Oceanography (SIO). Funding was provided by National Science Foundation grants OCE-0960770 (AJM), OCE-1419306 (AJM), and ARC-1107795 (IE). JLM and CAP were supported by the US Dept. of Energy's Office of Biological and Environmental Research in the Office of Science as part of a project named "Ultra High Resolution Global Climate Simulation to Explore and Quantify Predictive Skill for Climate Means, Variability and Extremes" and DOE DE-FG0205ER64119. The SIO Department generously provided salary support for LL during her final year at Scripps. The ocean/sea-ice simulation was conducted using computer resources (Yellowstone) (ark:/85065/d7wd3xhc) provided by the Climate Simulation Laboratory at NCAR's Computational and Information Systems Laboratory, sponsored by the National Science Foundation and other agencies. Computer resources were also provided by the National Energy Research Scientific Computing Center, which is supported by the Office of Science of the U.S. Department of Energy. Elena Yulaeva (SIO) is thanked for extracting the Bering Sea ocean and sea-ice model fields and for transferring them from the NSF computing facility at Yellowstone to SIO. 
Table 1. Model-Observation comparison of seasonal mean values

$\begin{array}{lllll} & \text { Fall } & \text { Winter } & \text { Spring } & \text { Summer } \\ \text { Model Ice Area }\left(10^{5} \mathrm{~km}^{2}\right) & 0.77 & 4.7 & 2.5 & .0076 \\ \text { Obs Ice Area }\left(10^{5} \mathrm{~km}^{2}\right) & 1.0 & 5.5 & 2.6 & .00007 \\ \text { Model Mean Ice Conc } & 0.44 & 0.78 & 0.55 & 0.26 \\ \text { Obs Mean Ice Conc } & 0.42 & 0.76 & 0.51 & 0.06 \\ \text { Rms error Ice Conc } & 0.43(0.43) & 0.16(0.16) & 0.22(0.22) & 4.9(30 .) \\ \text { Correlation Ice Conc } & 0.81(0.85) & 0.97(0.98) & 0.94(0.96) & -0.26(0.03)\end{array}$

Ice area and mean concentration (i.e., ice area divided by ice extent) are computed using only grid boxes with ice concentration greater than $15 \%$. The rms error between the model and the observations (which is normalized by the rms of the observations) and correlation between the model and the observations are computed over the area where both the model and the observations have ice concentration greater than 0 ; values computed over the area where either the model or the observations has ice concentration greater than 0 are given in parentheses. 


\section{References}

Auad, G., Miller, A.J., 2008. The role of tidal forcing in the Gulf of Alaska's circulation. Geophysical Research Letter 35, L04603.

Bitz, C.M., Lipscomb, W.H., 1999. An energy-conserving thermodynamic model of sea ice. Journal of Geophysical Research-Oceans 104, 15669-15677.

Bitz, C.M., Holland, M.M., Hunke, E.C., Moritz, R.E., 2005. Maintenance of the sea-ice edge. Journal of Climate 18, 2903-2921.

Cheng, W., Curchitser, E., Ladd, C., Stabeno, P., Wang, M., 2014. Influences of sea ice on the Eastern Bering Sea: NCAR CESM simulations and comparison with observations. Deep-Sea Research Part II-Topical Studies in Oceanography.

Comiso, J., 2000, updated 2012. Bootstrap sea ice concentrations from Nimbus-7 SMMR and DMSP SSM/I-SSMIS. Version 2. National Snow and Ice Data Center.

Craig, A.P., Vertenstein, M., Jacob, R., 2012. A new flexible coupler for earth system modeling developed for CCSM4 and CESM1. International Journal of High Performance Computing Applications 26, 31-42.

Danielson, S., Curchitser, E., Hedstrom, K., Weingartner, T., Stabeno, P., 2011. On ocean and sea ice modes of variability in the Bering Sea. Journal of Geophysical Research-Oceans 116, C12034.

Dukowicz, J.K., Smith, R.D., 1994. Implicit Free-Surface Method for the Bryan-CoxSemtner Ocean Model. J. Geophys. Res. 99, 7991-8014.

Griffies, S.M., Biastoch, A., Boning, C., Bryan, F., Danabasoglu, G., Chassignet, E.P., England, M.H., Gerdes, R., Haak, H., Hallberg, R.W., Hazeleger, W., Jungclaus, J., Large, W.G., Madec, G., Pirani, A., Samuels, B.L., Scheinert, M., Gupta, A.S., Severijns, C.A., Simmons, H.L., Treguier, A.M., Winton, M., Yeager, S., Yin, J., 2009. Coordinated Ocean-ice Reference Experiments (COREs). Ocean Model. 26, 1-46.

Griffies, S.M., Winton, M., Samuels, B., Danabasoglu, G., Yeager, S., Marsland, S., Drange, H., Bentsen, M., 2012. Datasets and protocol for the CLIVAR WGOMD Coordinated Ocean sea-ice Reference Experiments (COREs). WCRP, Report No. 21/2012

Gouretski, V.V., Koltermann, K.P., 2004. WOCE global hydrographic climatology. Technical 851 35, Bundesamtes für Seeschiffahrt und Hydrographie, Hamburg, 


\section{Germany.}

Haidvogel, D.B., Arango, H., Budgell, W.P., Cornuelle, B.D., Curchitser, E., Di Lorenzo, E., Fennel, K., Geyer, W.R., Hermann, A.J., Lanerolle, L., Levin, J., McWilliams, J.C., Miller, A.J., Moore, A.M., Powell, T.M., Shchepetkin, A.F., Sherwood, C.R., Signell, R.P., Warner, J.C., Wilkin, J., 2008. Ocean forecasting in terrain-following coordinates: Formulation and skill assessment of the regional ocean modeling system. J. Comput. Phys. 227(7), 3595-3624.

Hermann, A.J., Stabeno, P.J., Haidvogel, D.B., Musgrave, D.L., 2002. A regional tidal/subtidal circulation model of the southeastern Bering Sea: Development, sensitivity analyses and hindcasting. Deep Sea Research Part II: Topical Studies in Oceanography 49, 5495-5967.

Hunke, E.C., Maltrud, M., Hecht, M., 2008. On the grid dependence of lateral mixing parameterizations for global ocean simulations. Ocean Modelling 20, 115-133.

Hunke, E.C., Dukowicz, J.K., 1997. An elastic-viscous-plastic model for sea ice dynamics. Journal of Physical Oceanography 27, 1849-1867.

Hunt, G.L., Coyle, K.O., Eisner, L.B., et al., 2011. Climate impacts on eastern Bering Sea foodwebs: a synthesis of new data and an assessment of the Oscillating Control Hypothesis. Ices Journal of Marine Science 68, 1230-1243.

Ivanova, D.P., McClean, J.L., Hunke, E.C., 2012. Interaction of ocean temperature advection, surface heat fluxes and sea ice in the marginal ice zone during the North Atlantic Oscillation in the 1990s: A modeling study. Journal of Geophysical Research-Oceans 117, C02031.

Johnson, G.C., Stabeno, P.J., Riser, S.C., 2004. The Bering Slope Current system revisited. Journal of Physical Oceanography 34, 384-398.

Large, W.G., Yeager, S.G., 2004. Diurnal to decadal global forcing for ocean and sea-ice models: The data sets and flux climatologies. National Center for Atmospheric Research.

Large, W.G., Yeager, S.G., 2009. The global climatology of an interannually varying airsea flux data set. Climate Dynamics 33, 341-364.

Li, L., Miller, A.J., McClean, J.L., Eisenman, I., Hendershott, M.C., 2014. Processes driving sea ice variability in the Bering Sea in an eddying ocean/sea ice model: Anomalies from the mean seasonal cycle. Ocean Dynamics.

Lipscomb, W.H., Hunke, E.C., 2004. Modeling sea ice transport using incremental Remapping. Monthly Weather Review 132, 1341-1354.

Maslanik, J.A., Serreze, M.C., Barry, R.G., 1996. Recent decreases in Arctic summer sea 
ice cover and linkages to atmospheric circulation anomalies. Geophysical Research Letters 23(13), 1677-1680.

McClean, J.L., Bader, D.C., Bryan, F.O., Maltrud, M.E., Dennis, J.M., Mirin, A.A, Jones, P.W., Kim, Y.Y., Ivanova, D.P.,Vertenstein, M., Boyle, J.S., Jacob, R.L., Norton, N., Craig, A., Worley, P.H., 2011. A prototype two-decade fully-coupled fine-resolution CCSM simulation. Ocean Modelling 39, 10-30.

McClean, J.L., Hunke, E.C., Bailey, D., Papadopoulos, C., Yulaeva, E., 2014. Multidecadal CORE-forced global 0.1-deg coupled ocean/sea-ice simulations using the Community Earth System Model. In preparation.

McNutt, S.L., 1981a. Ice conditions in the eastern Bering Sea from NOAA and LANDSAT imagery: Winter conditions 1974, 1976, 1977, and 1979, 1981. NOAA Technical Memo, ERLPMEL-24. Seattle.

McNutt, S.L., 1981b. Remote sensing analysis of ice growth and distribution in the eastern Bering Sea, in: The eastern Bering Sea shelf oceanography and resources 1, 141-165.

Muench, R.D., Ahlnas, K., 1976. Ice movement and distribution in the Bering Sea from March to June 1974. Journal of Geophysical Research 81(24), 4467-4476.

Parkinson, C.I., Comiso, J.C., Zwally, H.J., Cavalieri, D.J., Gloersen, P., Campbell, W.J., 1987. Arctic sea ice, 1973-1976: satellite passive-microwave observations. Vol. 489. Washington DC: Scientific and Technical Information Branch, National Aeronautics and Space Administration.

Pease, C.H., 1980. Eastern Bering sea ice processes. Monthly Weather Review 108, 2015-2023.

Prasad, T.G., McClean, J.L., Hunke, E.C., Semtner, A.J., Ivanova, D., 2005. A numerical study of the western Cosmonaut polynya in a coupled ocean-sea ice model. Journal of Geophysical Research-Oceans 110, C10008.

Rigor, I., Colony, R., Martin, S., 2000. Variations in surface air temperature observations in the Arctic, 1979-1997. J Clim 13, 896-914.

Stabeno, P.J., Bond, N.A., Kachel, N.B., Salo, S.A., Schumacher, J.D., 2001. On the temporal variability of the physical environment of the southeastern Bering Sea. Fisheries Oceanography 10, 81-98.

Stabeno, P.J., James D.S., Kiyotaka O., 1999. The physical oceanography of the Bering Sea. Dynamics of the Bering Sea, 1-28.

Wang, J., Hu, H., Mizobata, K., Saitoh, S., 2009. Seasonal variations of sea ice and ocean 
circulation in the Bering Sea: A model-data fusion study. Journal of Geophysical ResearchOceans 114, C02011.

Wang, M., Overland, J.E., Stabeno, P., 2012. Future climate of the Bering and Chukchi Seas projected by global climate models. Deep-Sea Research Part II-Topical Studies in Oceanography 65, 46-57.

Zhang, J., Rothrock, D., Steele, M., 2000. Recent changes in arctic sea ice: The interplay between ice dynamics and thermodynamics. Journal of Climate 13(17), 3099-3114.

Zhang, J.L., Rothrock, D., 2001. A thickness and enthalpy distribution sea-ice model. Journal of Physical Oceanography 31, 2986-3001.

Zhang, J.L., Woodgate, R., Moritz, R., 2010. Sea ice response to atmospheric and oceanic forcing in the Bering Sea. Journal of Physical Oceanography 40, 1729-1747.

Zhang, Y., Rossow, W., Lacis, A., Oinas, V., Mishchenko, M., 2004. Calculation of radiative flux profiles from the surface to top-of-atmosphere based on ISCCP and other global data sets: Refinements of the radiative transfer model and the input data. J. Geophys. Res. 109, D19.

\section{Figure captions}

Figure 1 Bathymetry of the Bering Sea (contours) and the model temperature grid points (white dots) subsampled every 10 points. The bathymetry is from the POPCICE model ocean depth at temperature grid points. The 2 black boxes show study areas for Figures 8 and 11. Locations of places mentioned in the text are indicated.

Figure 2 (a) Total ice area in the Bering Sea for POP-CICE model (red) and satellite passive microwave observations (blue) for each month (circles) during 1980-1989. Total ice area is computed as the sum of the ice area in each grid box with ice concentration greater than 15\%. (b) Monthly-mean seasonal cycle of total ice area for the model (red) and observations (blue).

Figure 3 Ice concentrations from the POP-CICE model (top a-d), Bootstrap satellite passive microwave observations (middle e-h), and the difference between model and observation (bottom i-l). Seasonal means during 1980-1989 for fall (OctoberDecember), winter (January-March), spring (April-June), and summer (JulySeptember) are shown from left to right.

Figure 4 (a) Fall ice volume tendency (sum of dynamic tendency and thermodynamic tendency, $\left.\frac{V}{t}\right)$, (b) dynamic tendency $\left(\frac{V_{D}}{t}\right)$, and (c) 
thermodynamic tendency (sum of basal melt rate, lateral melt rate, and surface melt rate, $\frac{V_{T}}{t}$ ), (d) ice growth rate $\mathrm{G}$ (sum of frazil ice growth, congelation ice growth, and snow ice formation), (e) basal plus lateral melt rate $\mathrm{M}_{\mathrm{BL}}$, and (f) surface melt rate Ms. Note that melt rates in (e) and (f) are depicted as negative values. White lines represent contours of $15 \%, 50 \%$, and $85 \%$ ice concentration. Volume is normalized by the grid cell area, giving units of thickness $(\mathrm{cm})$ for each panel.

Figure 5 As in Figure 4 but for Winter.

Figure 6 As in Figure 4 but for Spring.

Figure 7 As in Figure 4 but for Summer.

Figure 8 Monthly climatology of the thermodynamic, dynamic, and total ice volume tendencies averaged over each of the 2 boxes (shown in Figure 1) in the key growth (north) and melt (south) regions.

Figure 9 Monthly climatology of the thermodynamic, dynamic, and total ice volume tendencies summed over all the grid cells in the Bering Sea.

Figure 10 Seasonal mean of (top a-d) atmospheric wind and temperature, (middle e-h) ice velocity and thickness, and (bottom i-l) ocean surface velocity and temperature for (left to right) fall, winter, spring and summer. The $15 \%$ ice concentration contour is shown in black.

Figure 11 Monthly climatology of surface and ocean energy flux and wind stress on ice averaged over each of the 2 boxes (shown in Figure 1) in the key growth (north) and melt (south) regions.

Figure 12 (a) Winter net surface energy flux, (b) winter net shortwave radiation, (c) winter latent heat flux, (d) winter ocean heat flux, (e) winter net longwave radiation, (f) winter sensible heat flux, (g) spring net surface energy flux, (h) spring net shortwave radiation, (i) spring latent heat flux, (j) spring ocean heat flux, (k) spring net longwave radiation, (l) spring sensible heat flux. Positive values indicate downward energy flux. Note that the subtle checkered patterns in the atmospheric forcing fields are expected to be associated with regridding from the CORE2 grid to the model grid.

Figure 13 Winter magnitudes of (a) wind stress on ice, (b) ocean stress on ice, (c) the Coriolis force, (d) divergence of the internal ice stress tensor, (e) gravitational force due to sea surface slope, and (f) net force; panels (a)-(f) are all plotted with the same color range. Winter magnitudes of $(\mathrm{g})$ the sum of wind stress and ocean stress, 
(h) the Coriolis force, (i) divergence of the internal ice stress tensor, and (j) gravitational force due to sea surface slope; panels (g)-(j) are all plotted with the same color range.

Figure 14 As in Figure 13 but for Spring.

Figure 15 Schematic of the large-scale Bering Sea winter sea ice balance, summarizing our main results. Cold northeasterly wind (black arrows) drives the strongest ice growth (lavender) in the northeast. Ice moves (white arrows) southwestward towards the strongest melting region (rose), which is warmed by the Bering Slope Current (blue arrows). These patterns drive the basin-wide asymmetry and the $\mathrm{S}$-shaped ice edge. The modeled winter sea ice balance is shown in Figure 5. 

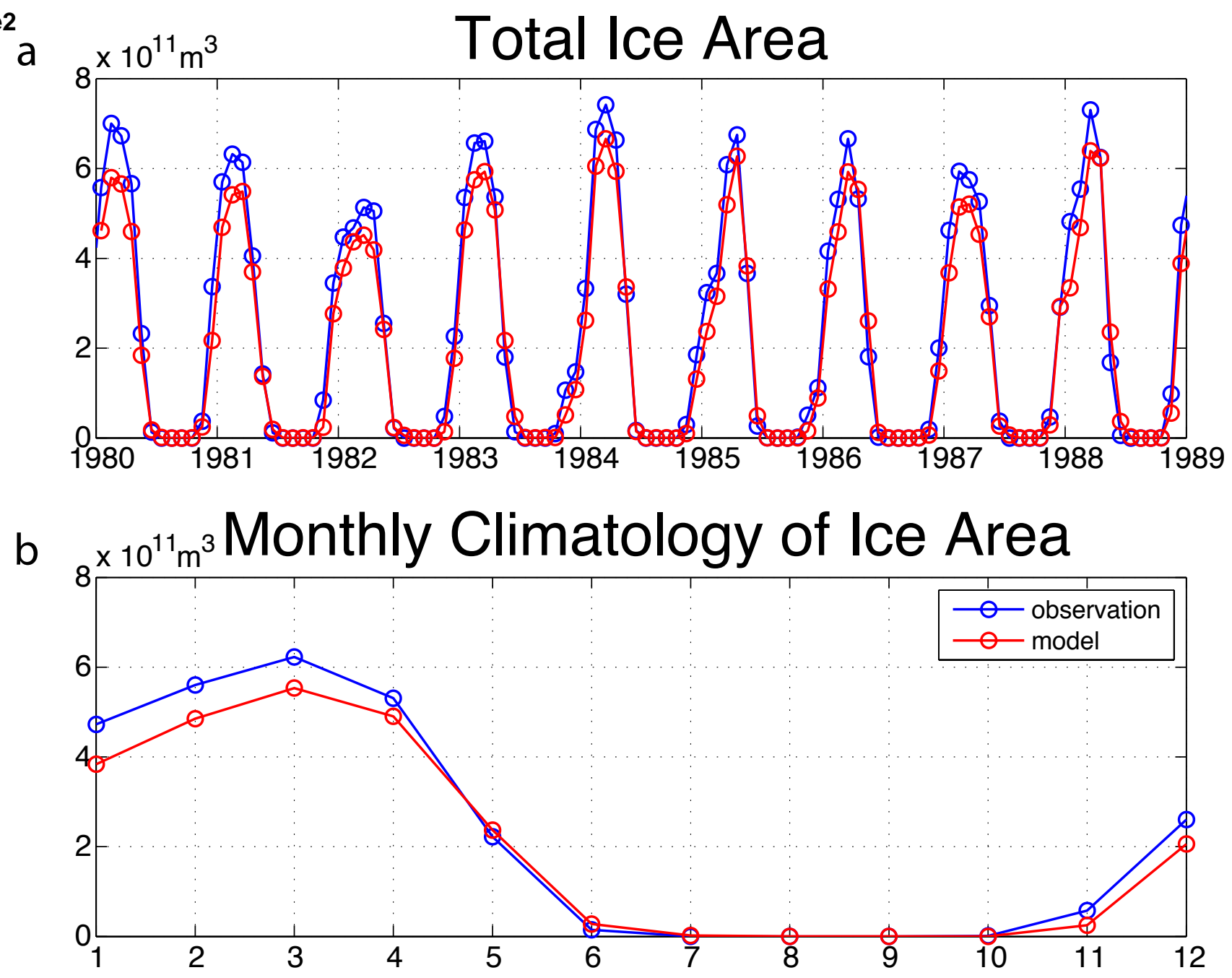


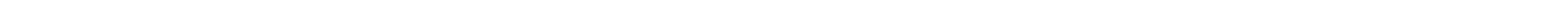


Winter Volume Tendency (cm/day)

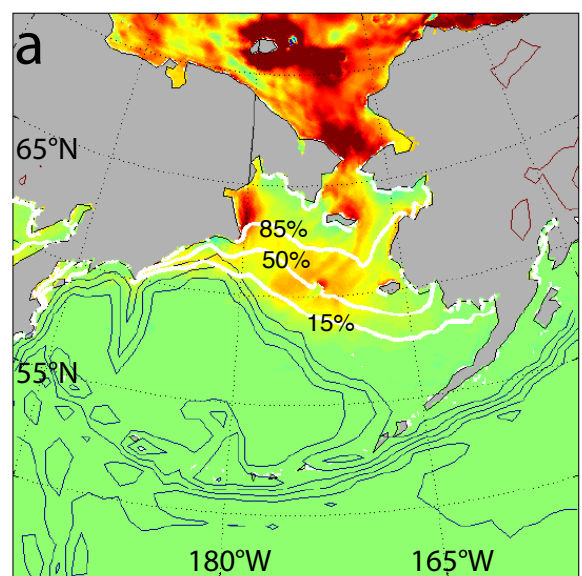

Winter Growth Rate (cm/day)

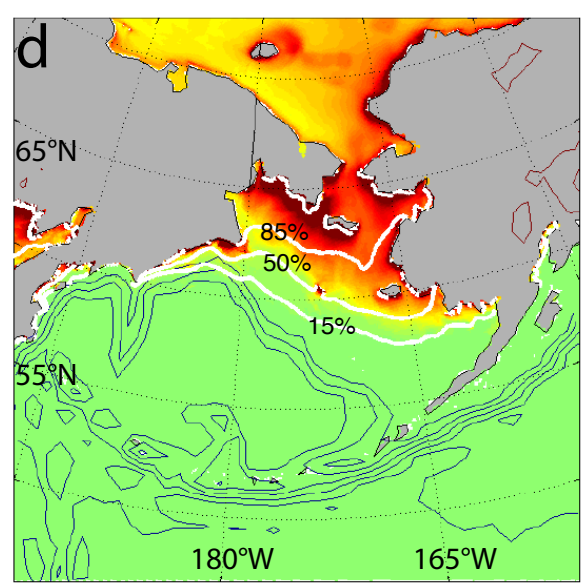

Winter Dynamic Volume Tendency (cm/day)

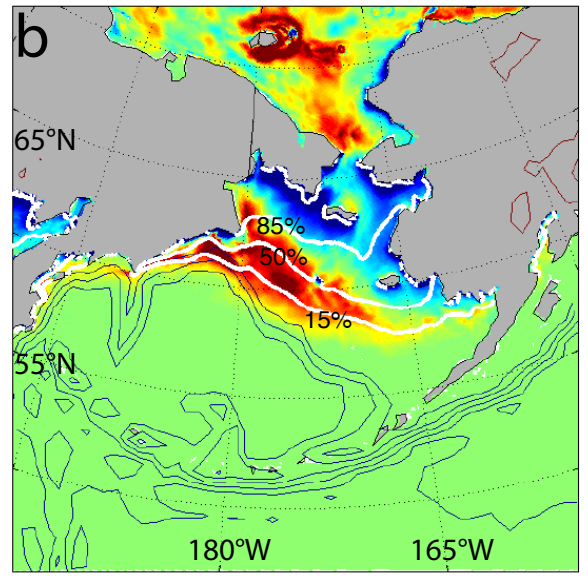

Winter Basal + Lateral Melt (cm/day)

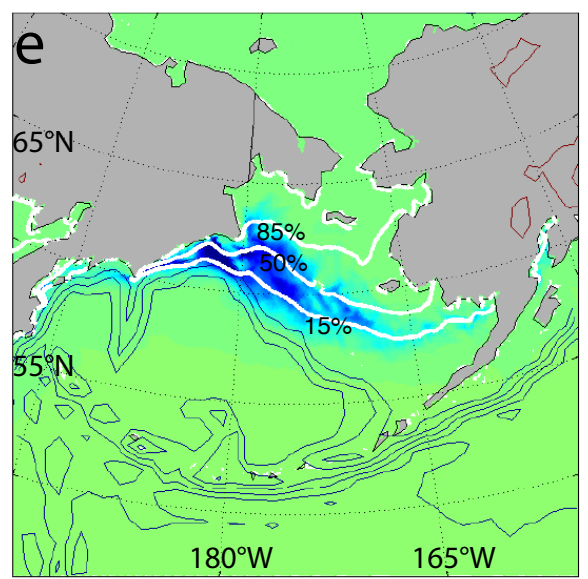

Winter Thermodynamic Volume Tendency (cm/day)

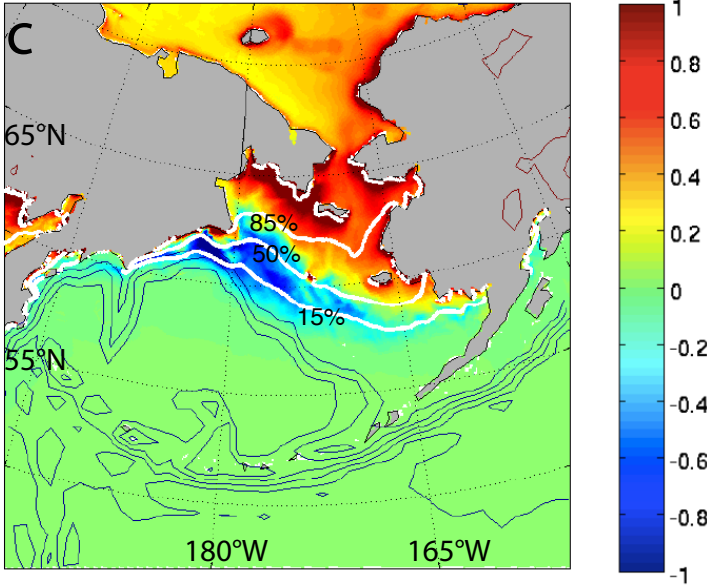

$\mathrm{cm} /$ day

Winter Top Surface Melt (cm/day)

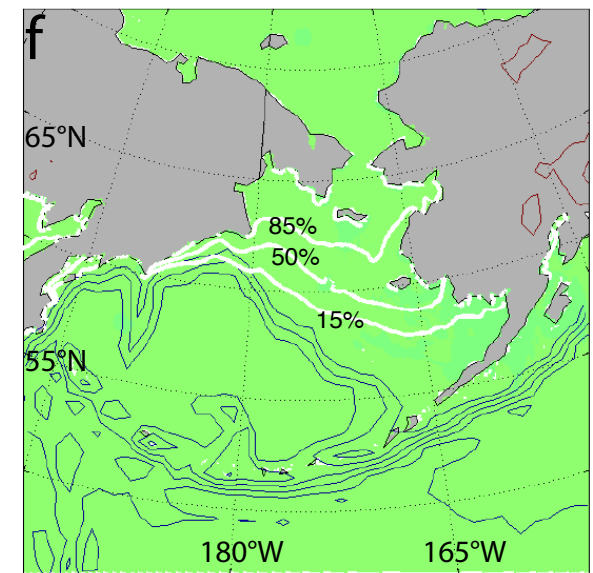


Spring Volume Tendency (cm/day)

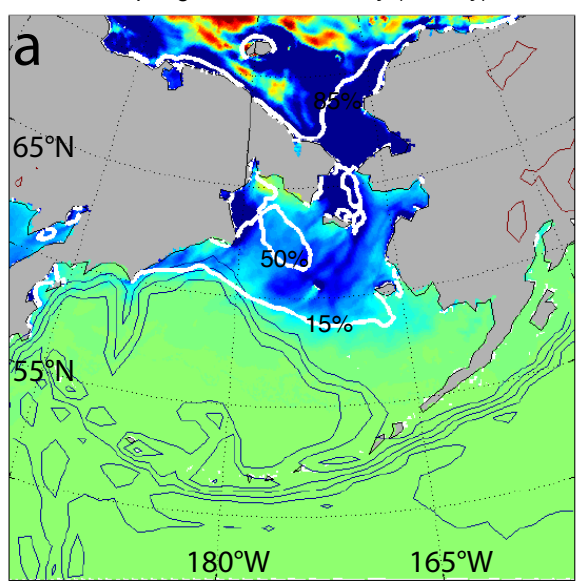

Spring Growth Rate (cm/day)

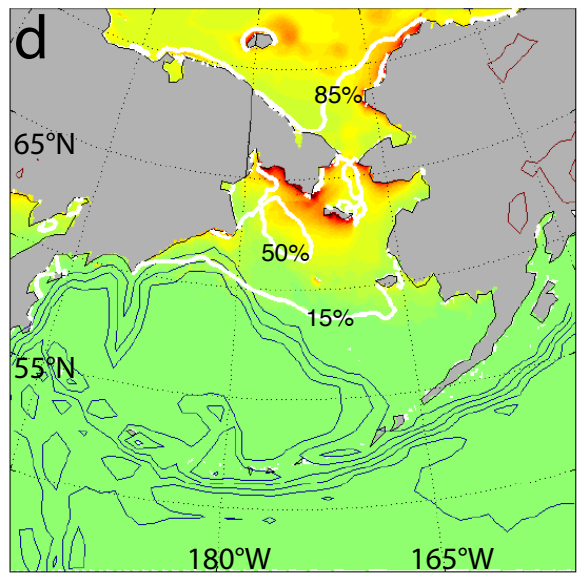

Spring Dynamic Volume Tendency (cm/day)

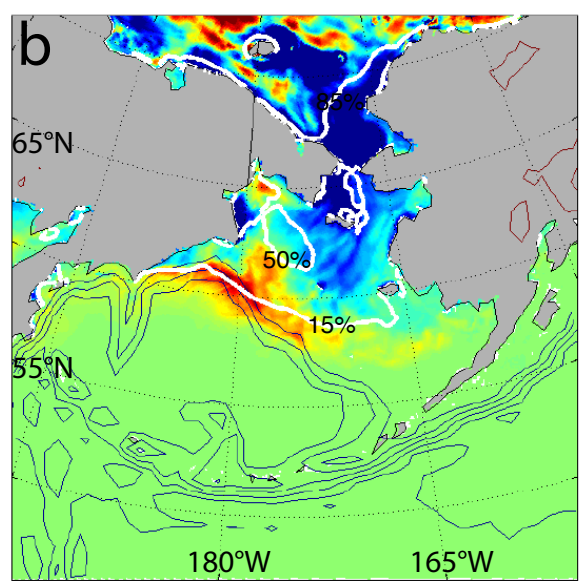

Spring Basal + Lateral Melt (cm/day)

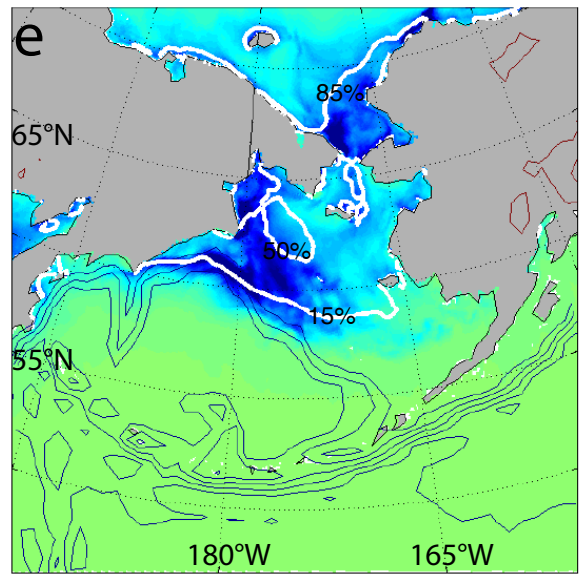

Spring Thermodynamic Volume Tendency ( $\mathrm{cm} /$ day)

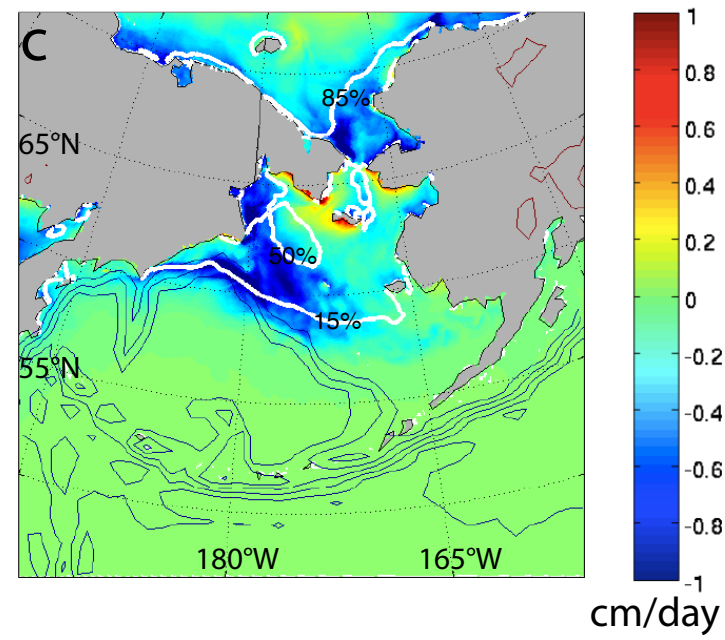

Spring Top Surface Melt (cm/day)

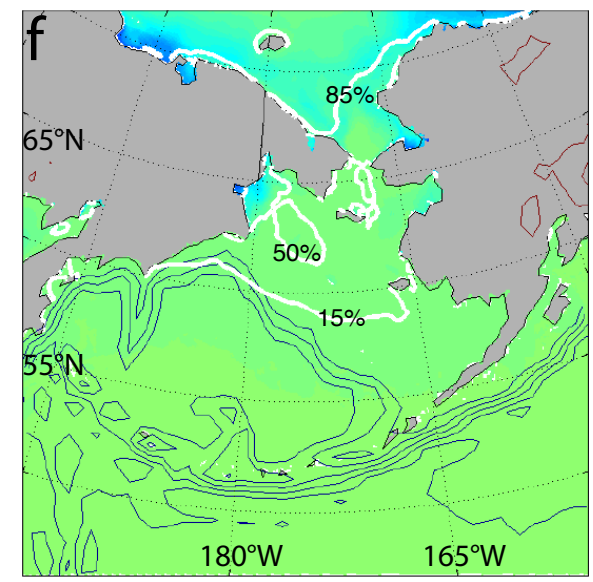


Summer Volume Tendency (cm/day)

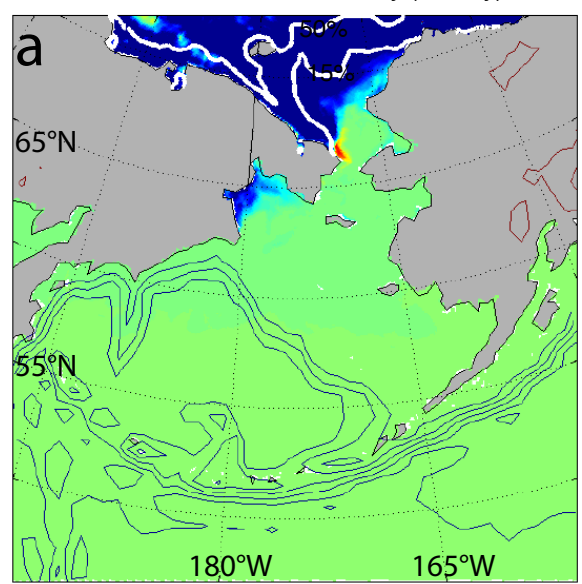

ummer Growth Rate (cm/day)

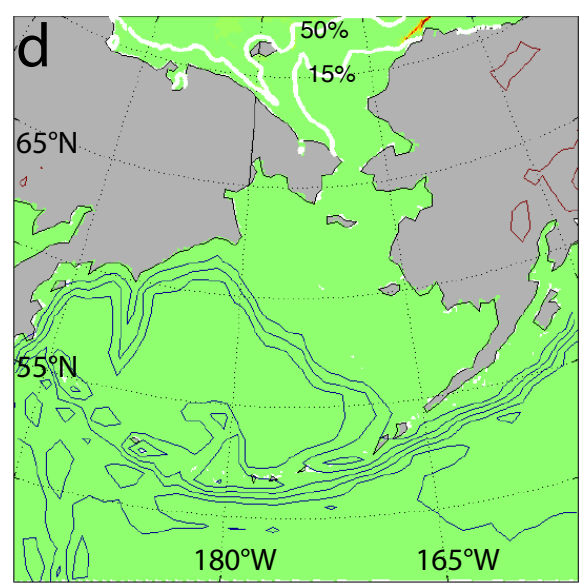

Summer Dynamic Volume Tendency (cm/day)

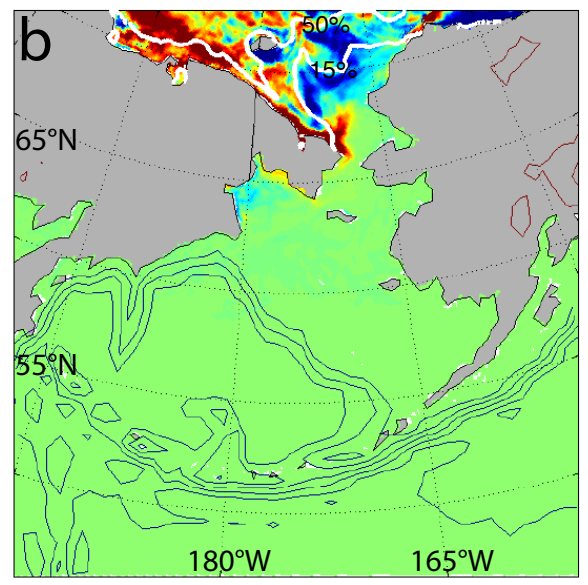

Summer Basal + Lateral Melt (cm/day)

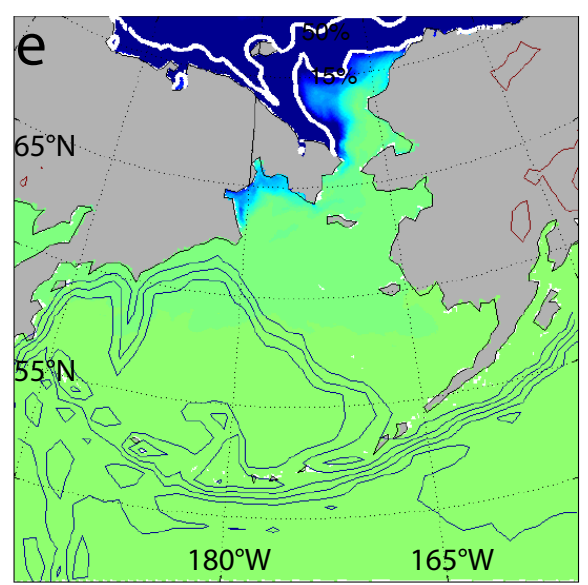

Summer Thermodynamic Volume Tendency (cm/day)

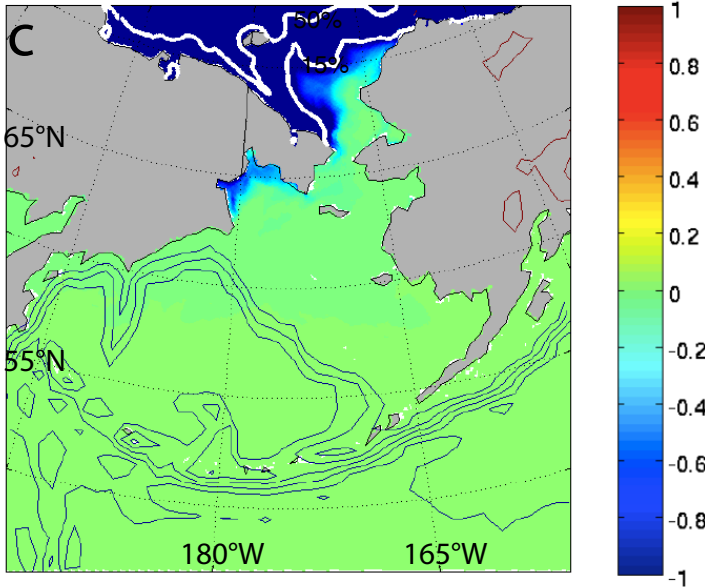

$\mathrm{cm} /$ day

Summer Top Surface Melt (cm/day)

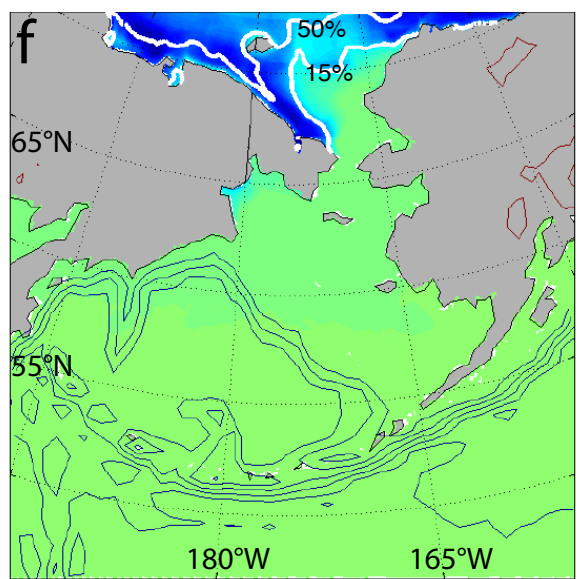




\section{Figure8}

Ice Volume Tendency Climatology at Growth Site

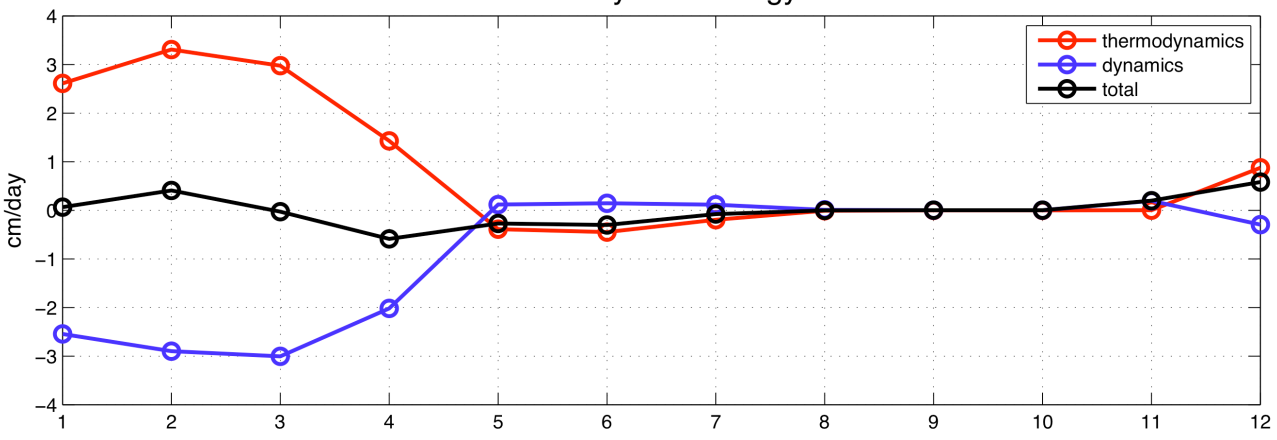

Ice Volume Tendency Climatology at Melt Site

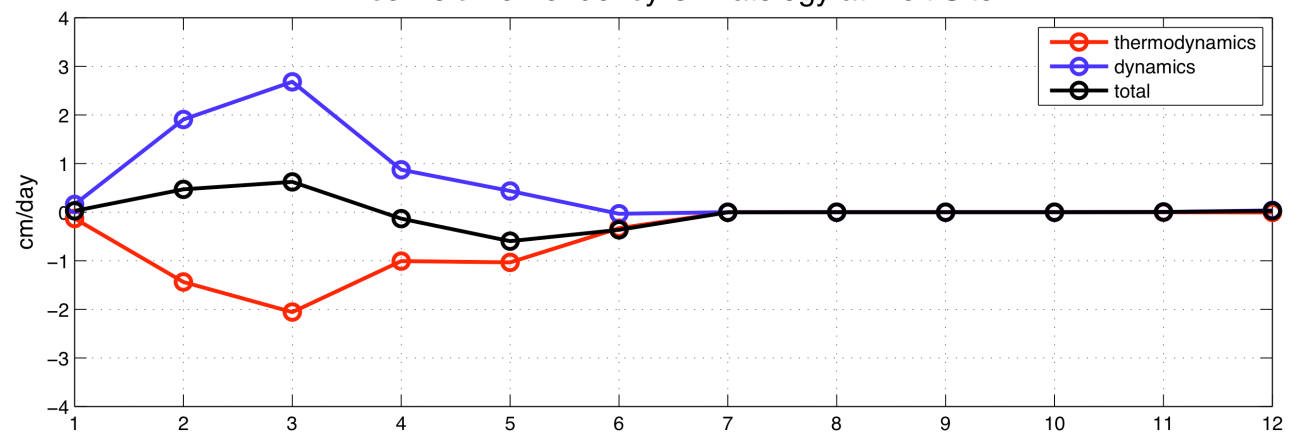


Figure9

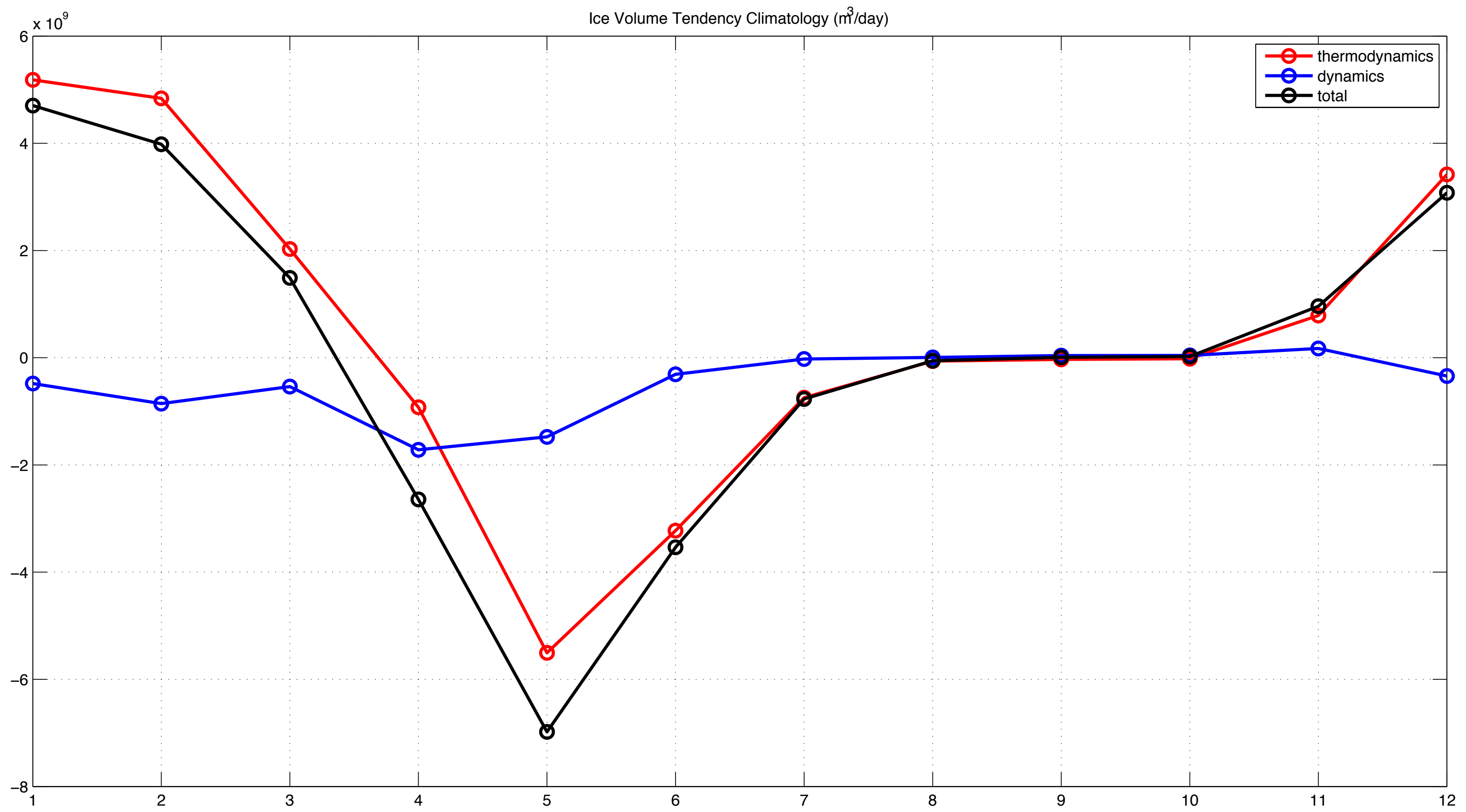




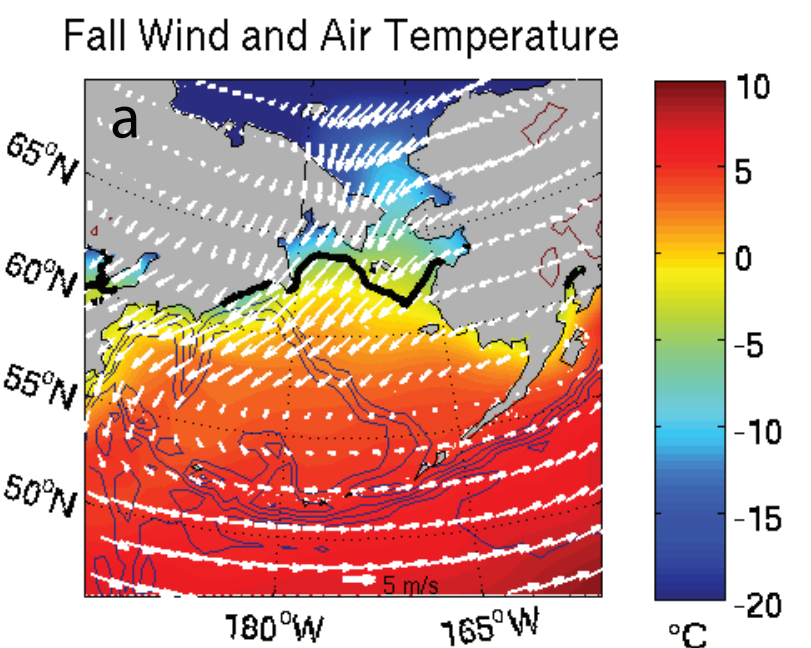

Fall Ice Velocity and Thickness

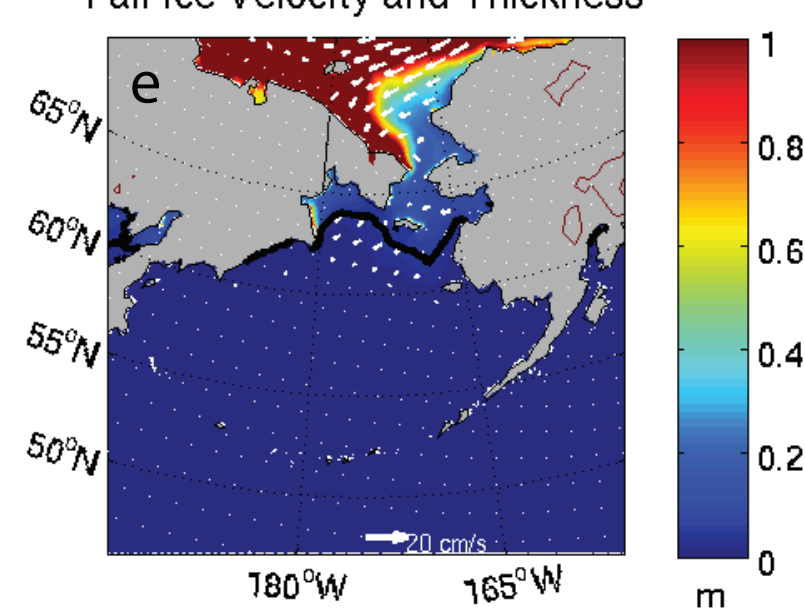

Fall Ocean Surface Velocity and Temperature

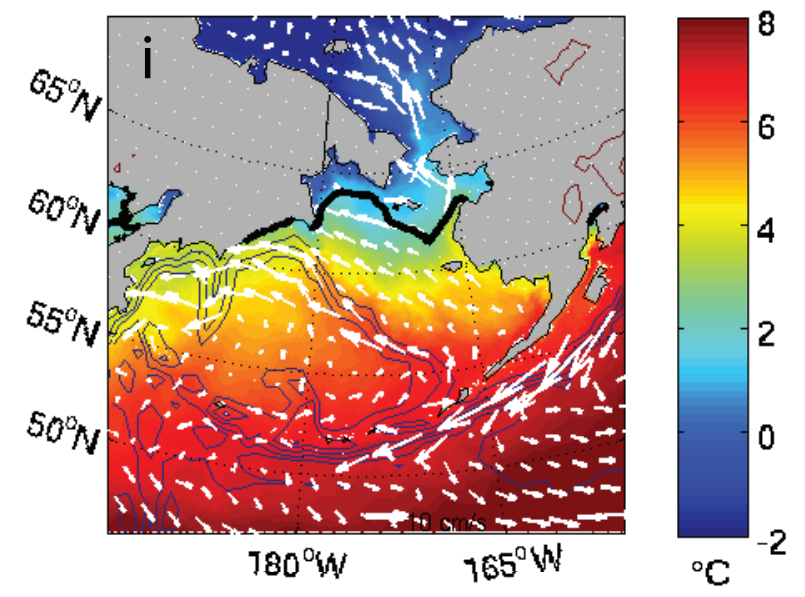

Winter Wind and Air Temperature

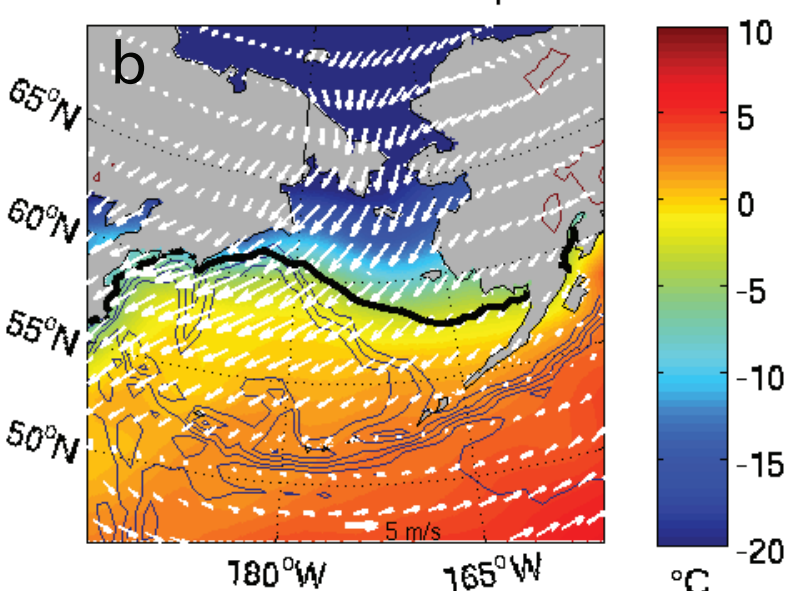

Winter Ice Velocity and Thickness

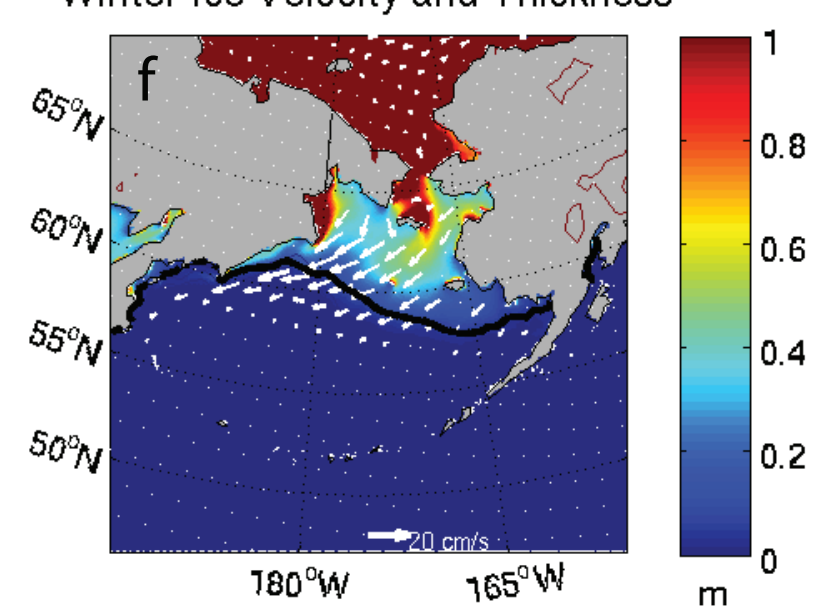

Winter Ocean Surface Velocity and Temperature



Spring Wind and Air Temperature

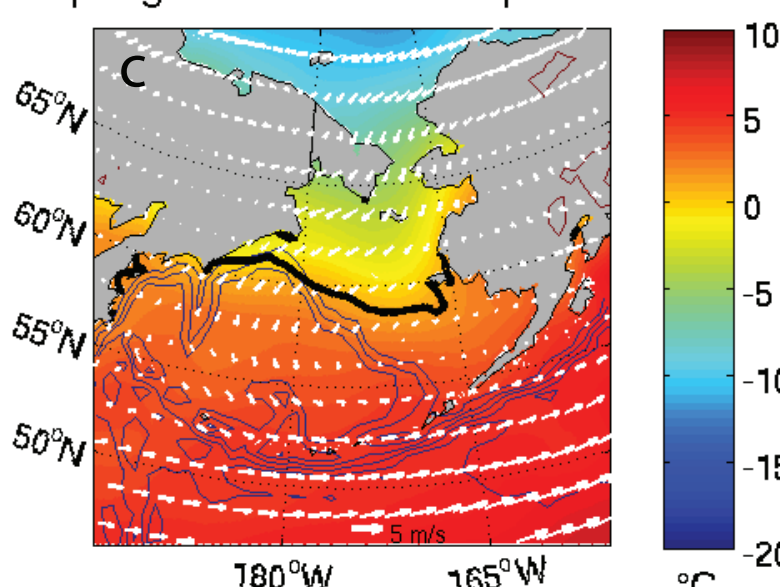

Spring Ice Velocity and Thickness

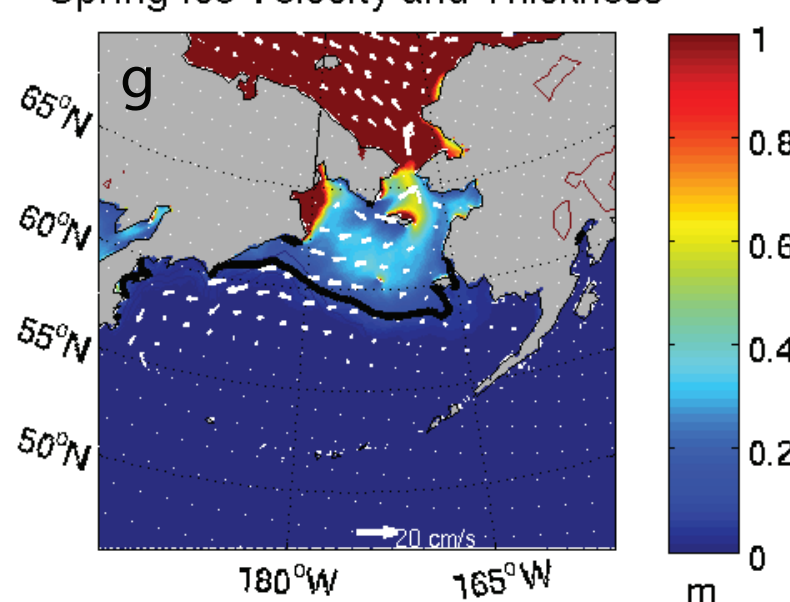

Spring Ocean Surface Velocity and Temperature

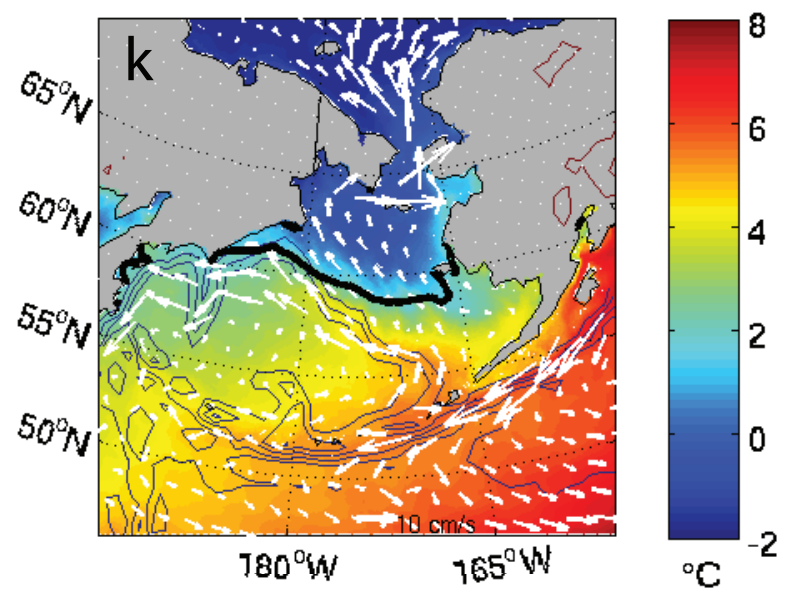

Summer Wind and Air Temperature

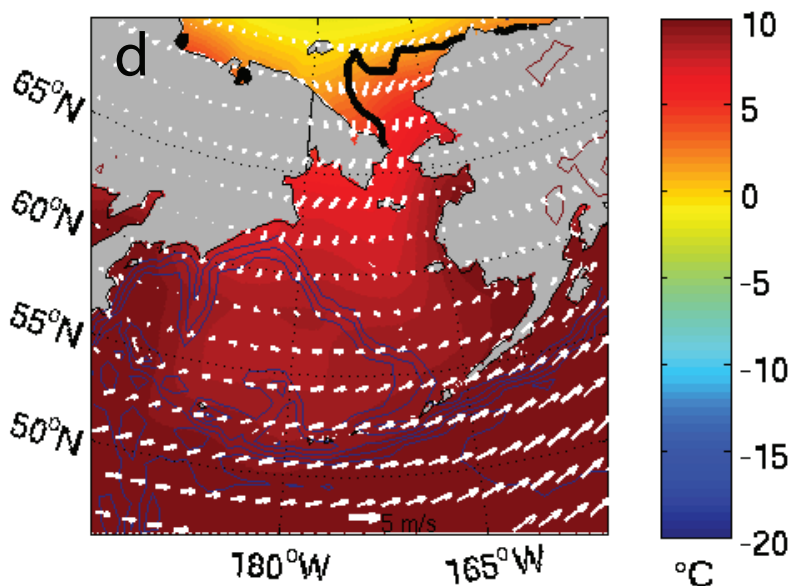

Summer Ice Velocity and Thickness

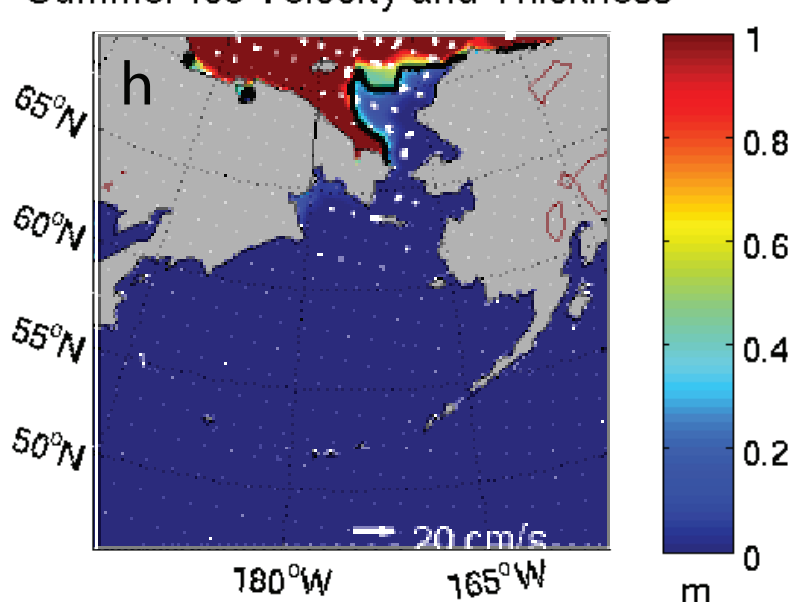

Summer Ocean Surface Velocity and Temperature

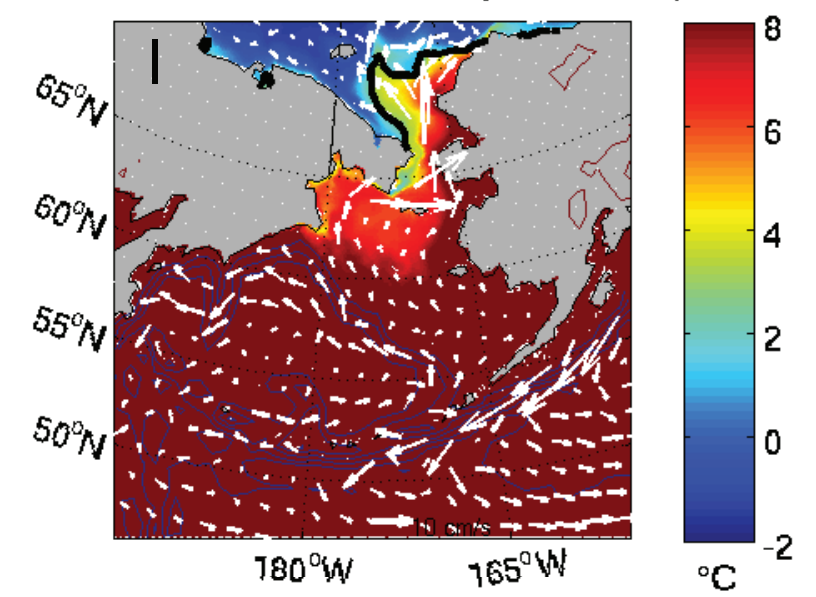


Figure11
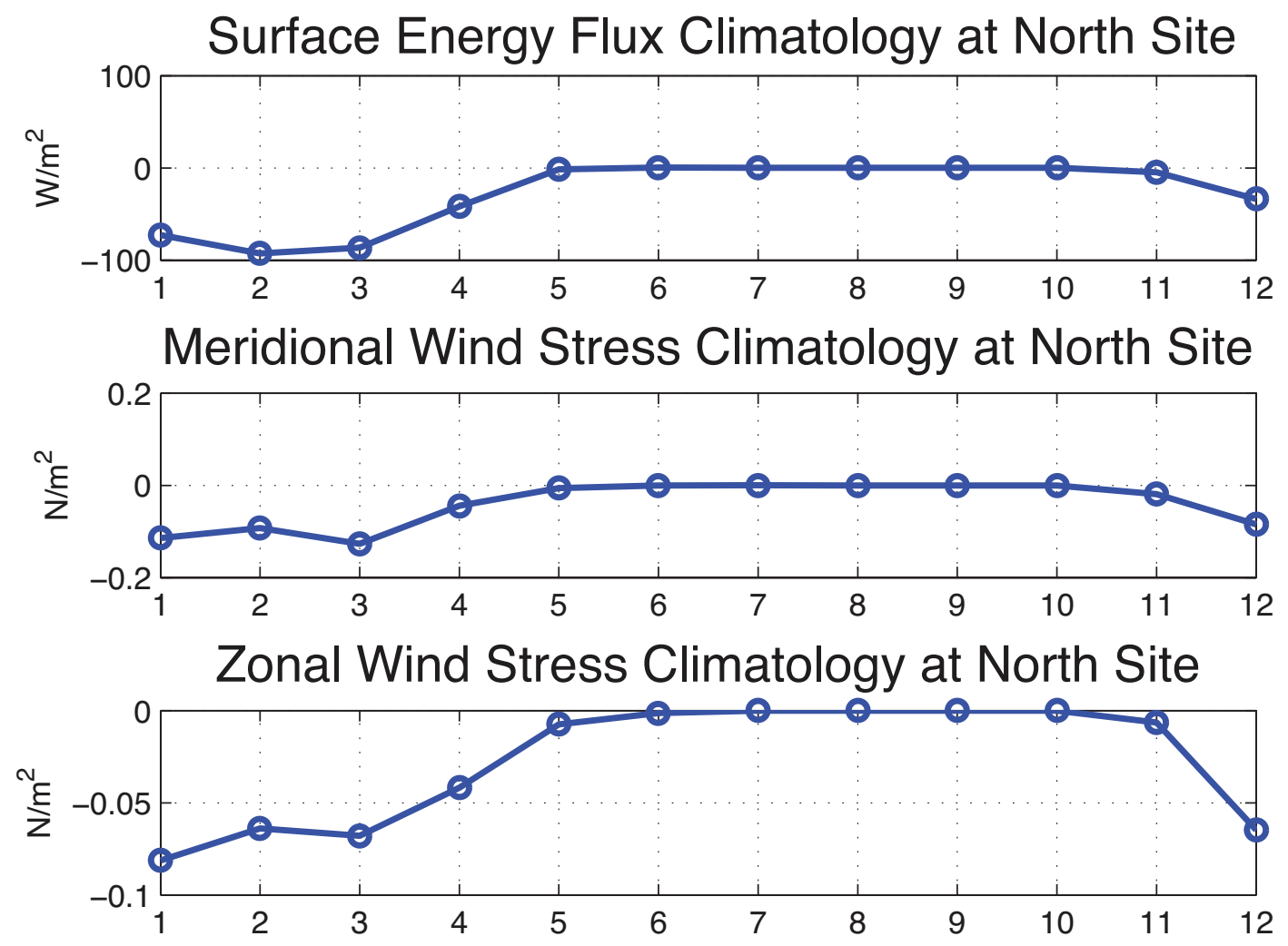

Ocean Heat Flux Climatology at South Site

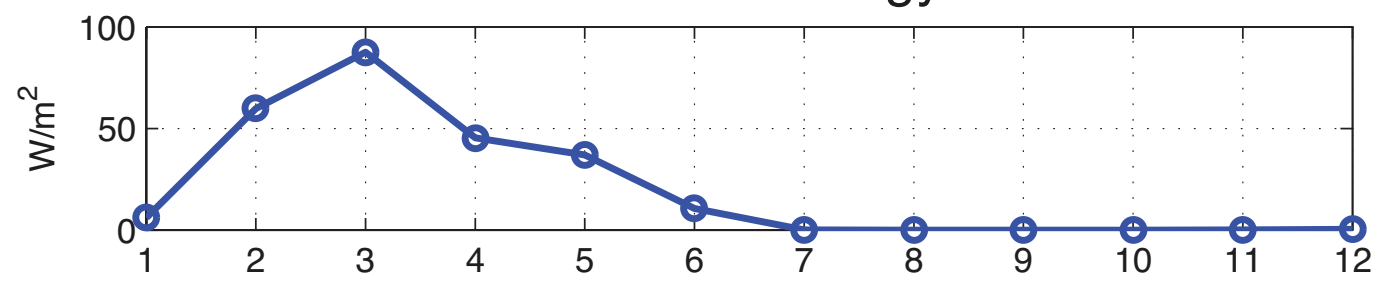

Meridional Wind Stress Climatology at South Site
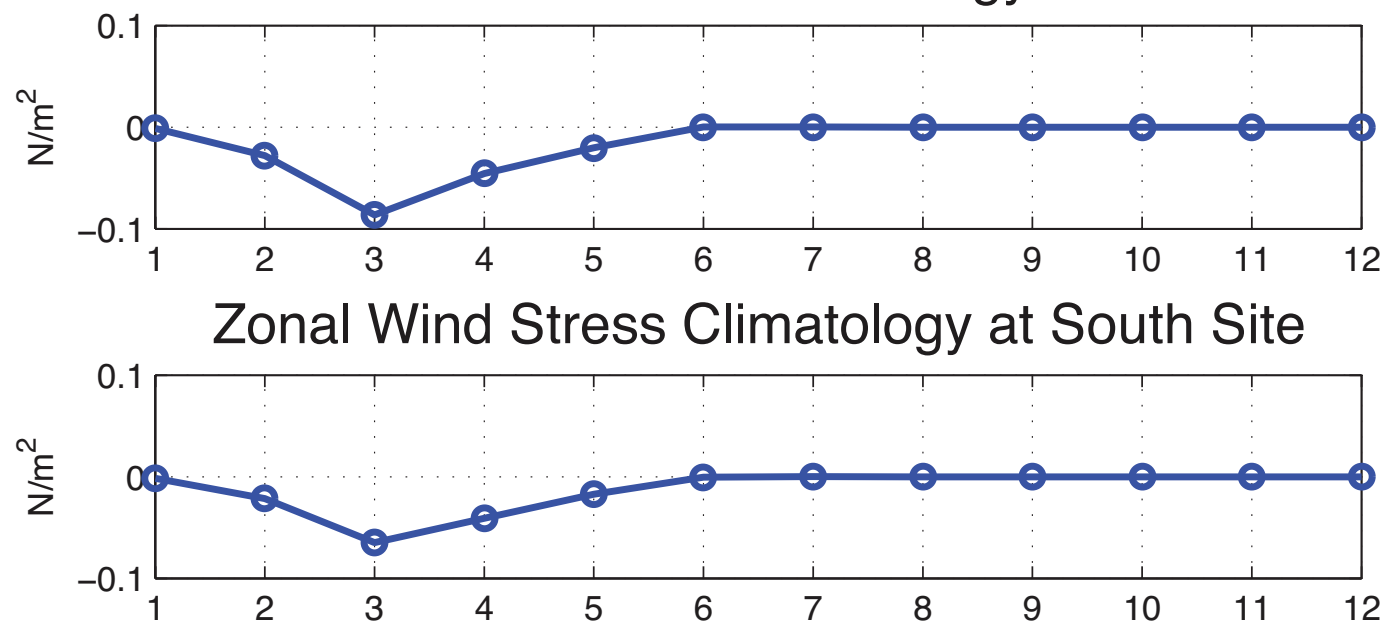
a Winter Surface Energy Flux

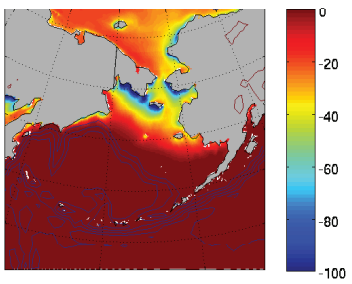

d Winter Ocean Heat Flux

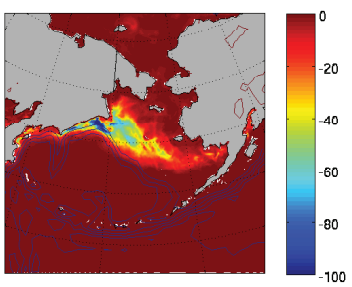

$9 \quad$ Spring Surface Energy Flux

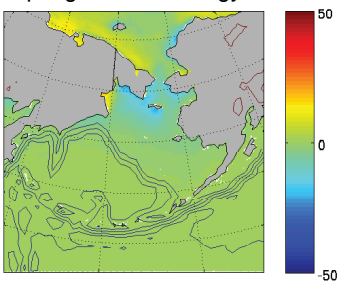

Spring Ocean Heat Flux
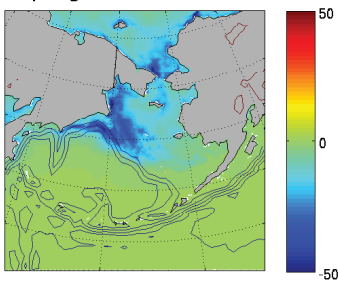

b Winter Shortwave Radiation

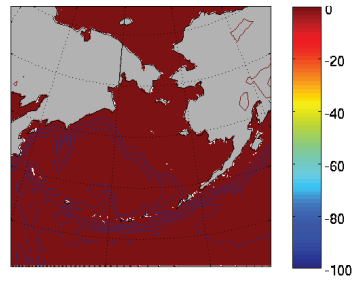

e Winter Longwave Radiation

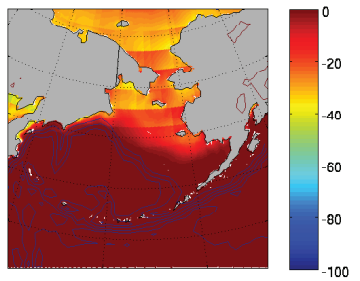

h Spring Shortwave Radiation

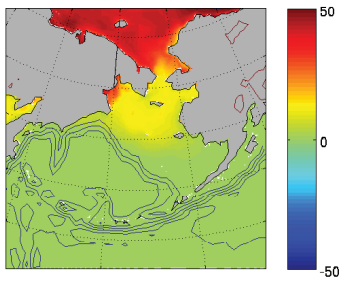

k Spring Longwave Radiation

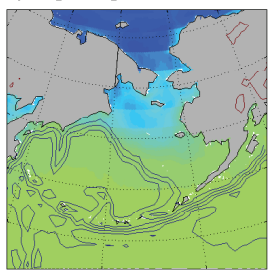

C Winter Latent Heat Flux

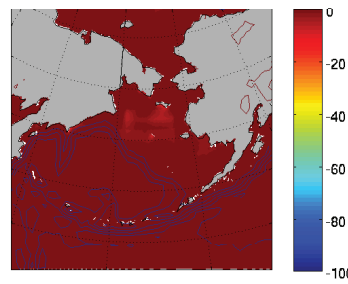

f

Winter Sensible Heat Flux
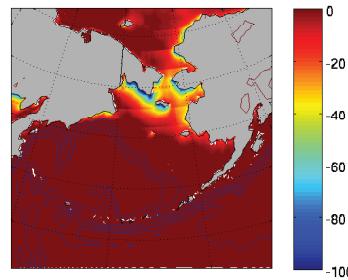

i Spring Latent Heat Flux

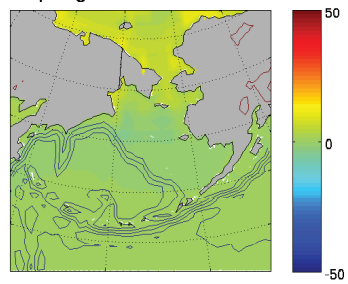

I Spring Sensible Heat Flux

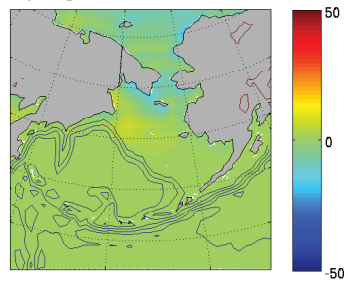




\section{a Winter Wind Stress}

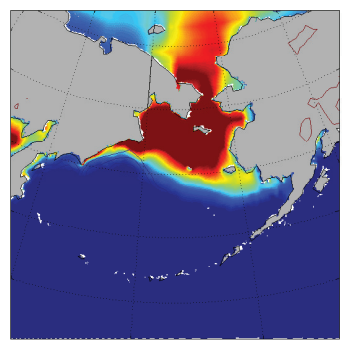

d Winter Internal Ice Stress

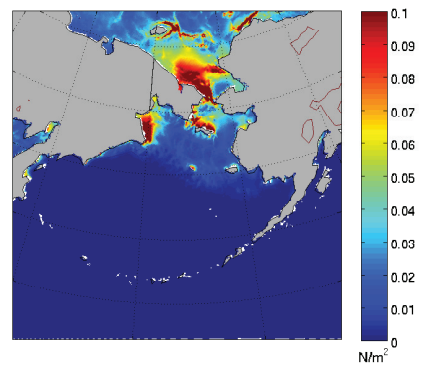

b

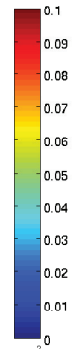

$\mathrm{N}^{2} \mathrm{H}^{2}$

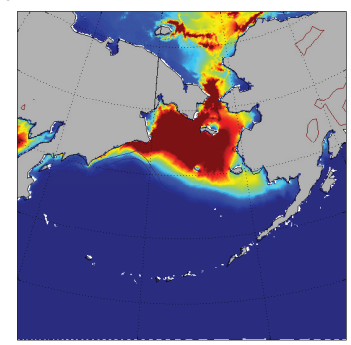

€ Winter Force due to Sea Surface Slope

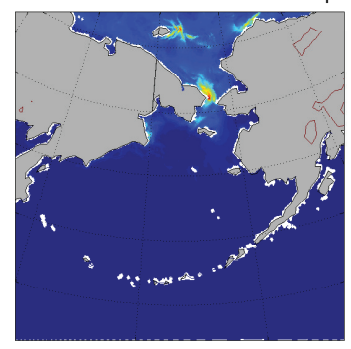

c Winter Coriolis Force

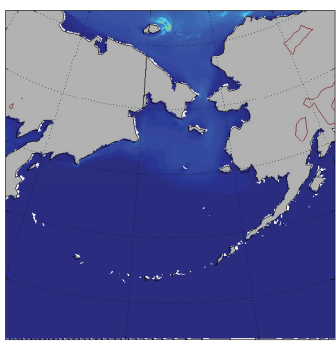

f

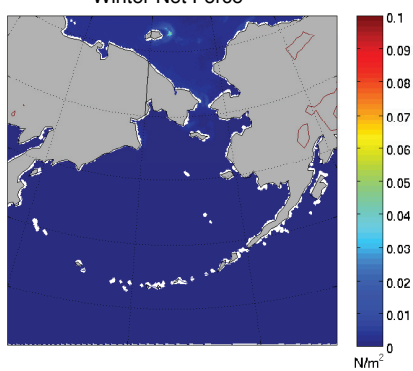

g Winter Wind Stress+Ocean Stress
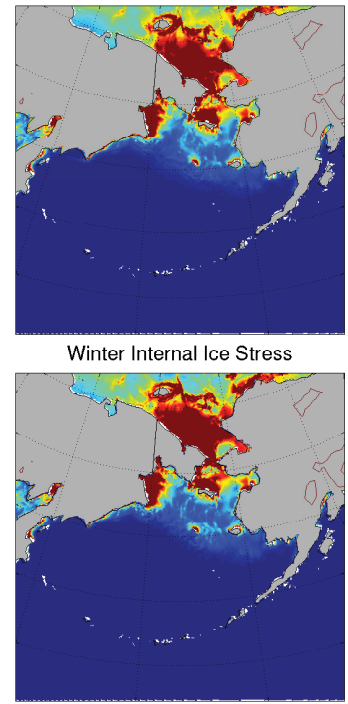

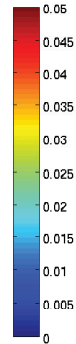

$\mathrm{N} / \mathrm{m}^{2}$

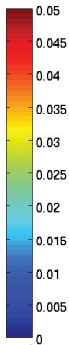

$\mathrm{N} / \mathrm{m}^{2}$ h Winter Coriolis Force

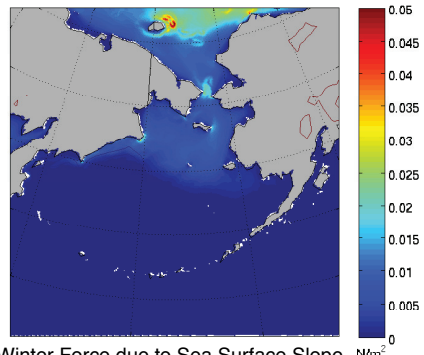

j Winter Force due to Sea Surface Slope

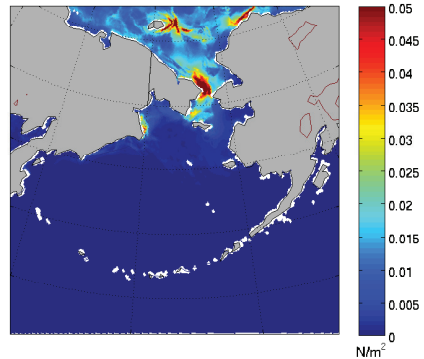


a Spring Wind Stress

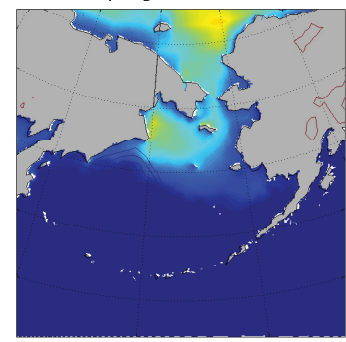

d

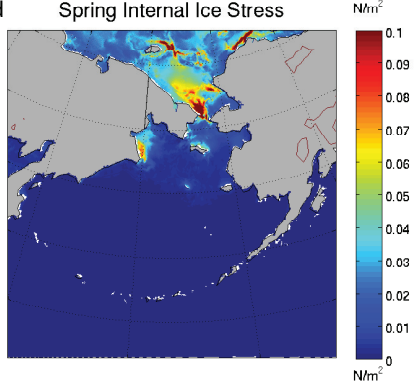

b

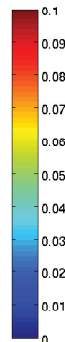

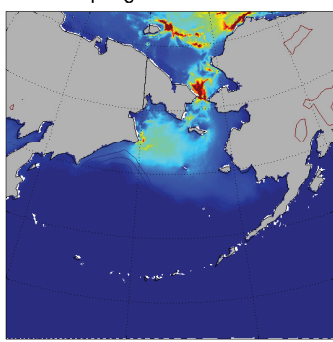

( Spring Force due to Sea Surface Slope

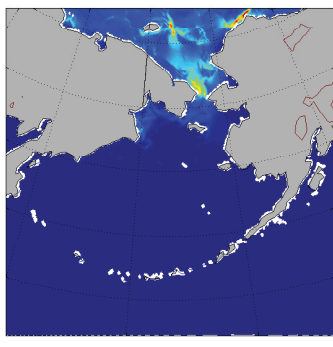

C Spring Coriolis Force

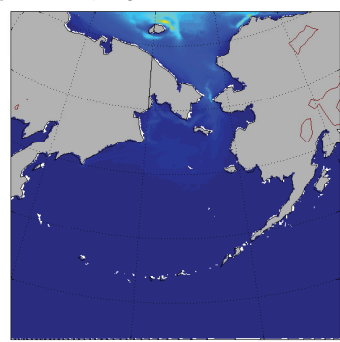

f

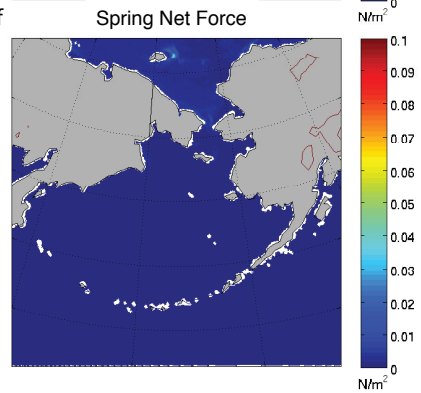

g Spring Wind Stress + Ocean Stress

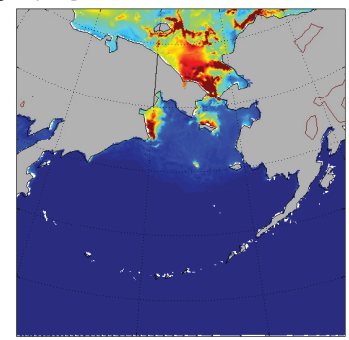

i

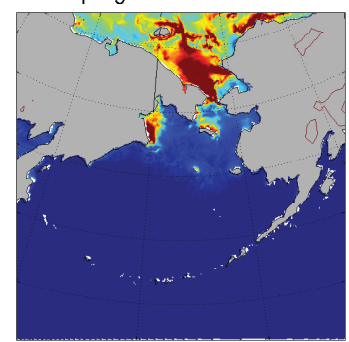

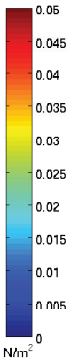

0.05

$-0.045$

0.04

$-n \cap 35$

$-0.03$

$-0.025$

$-0.02$

$-0.015$

$-0.01$

0.005

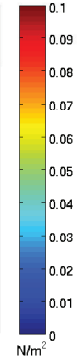

h

Spring Coriolis Force

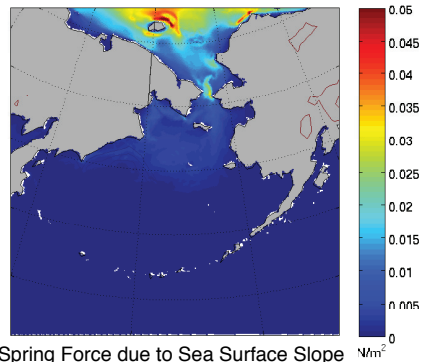

j Spring Force due to Sea Surface Slope

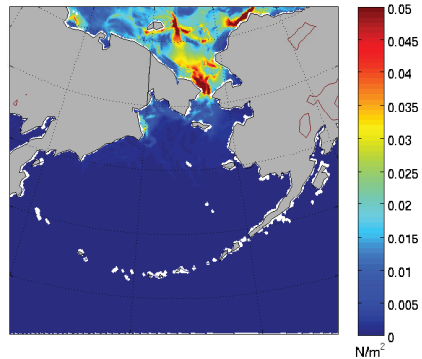




\section{Bering Sea Winter}

Ice Balance

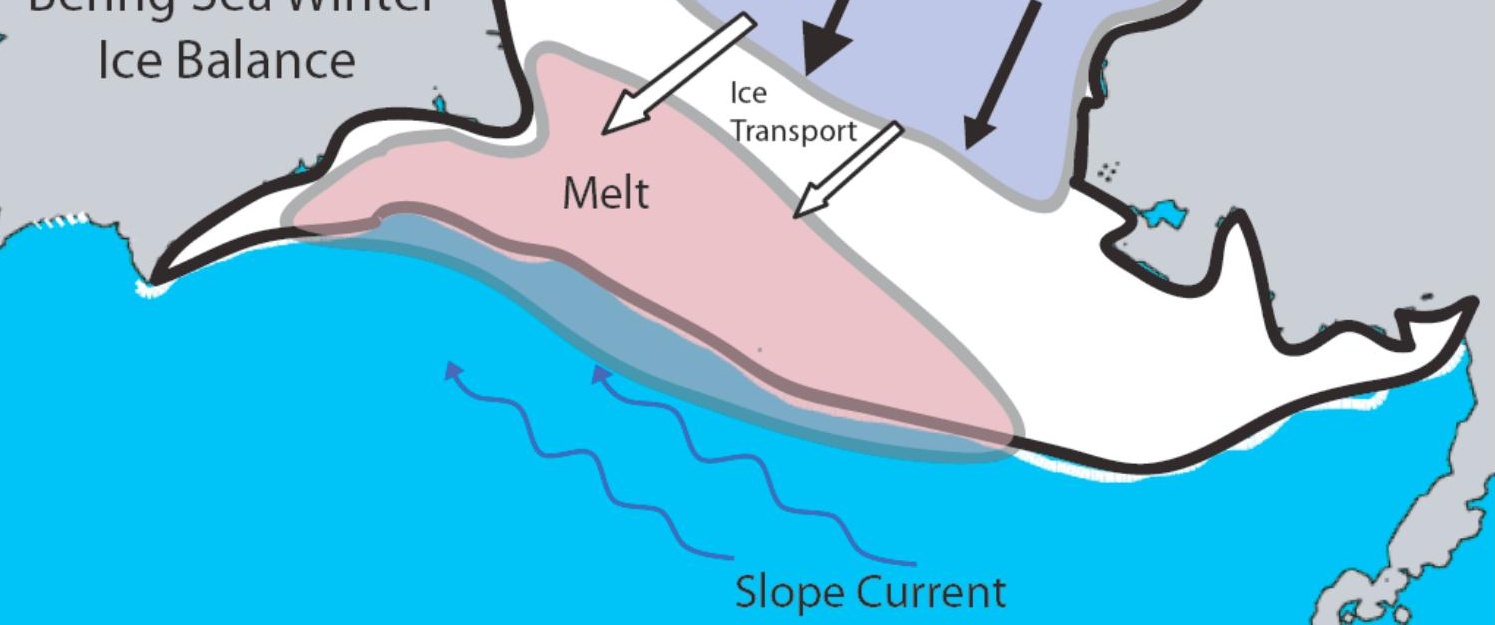

